\title{
Palestrina and the Influence of "Old" Style in Eighteenth-Century Vienna
}

\author{
JEN-YEN CHEN
}

Vienna, Austria

\begin{abstract}
During the eighteenth century, the Palestrina style remained an actively cultivated idiom in major musical centers of Europe. This persistent interest in the stile antico did not manifest a historicist mindset, however; rather, it stemmed from a desire to promote specific values epitomized by Palestrina's compositions and apply these to modern music. Johann Joseph Fux, the central figure in the Viennese stile antico tradition, provides an instructive example. A detailed reading of the Gradus ad Parnassum (1725) reveals that Fux exploited the Palestrina mystique in order to advocate his own ideals and "rescue" contemporary music from an alleged state of corruption. At the heart of his thinking stood a belief that truly good music resulted from the observance of immutable principles embodied in Palestrina's works. The timeless quality of the stile antico is illustrated through analyses of Masses by Fux, Georg Reutter, and Johann Georg Albrechtsberger, which trace the gradual adaptation of the classical vocal polyphony to the language of functional tonality. This development, confirmed by theoretical writings such as Albrechtsberger's Gründliche Anweisung zur Composition (1790), demonstrates that the stile antico could transcend the stylistic conditions of particular historical eras.
\end{abstract}

Throughout the eighteenth century, the Palestrina style remained an actively cultivated musical language in both Catholic and Protestant regions of central Europe. It coexisted comfortably with more modern compositional approaches and helped to shape a diverse musical landscape in which a variety of idioms exerted a mutual influence on

Earlier versions of this article were delivered at the seventeenth congress of the International Musicological Society, which took place in August 2002 in Leuven, Belgium, and at the Winter 2001 meeting of the New England Chapter of American Musicological Society in Providence, RI. I wish to thank Bruce C. Macintyre for reading a draft of this article and offering many helpful comments and suggestions. 
one another. The so-called stile antico did not represent an isolated realm that lay outside the mainstream of compositional practice; rather, it defined this mainstream in important ways, by embodying principles of voice leading that applied to all music of the period. A1though the label antico suggests a historicist mindset, with "old" providing a specific orientation in time, in fact musicians of the eighteenth century did not possess a strong historical consciousness. No composer attempted a faithful imitation of Palestrina, and verisimilitude in reconstructing the musical language of a bygone age did not constitute a goal of the Palestrina style. ${ }^{1}$ The motivation for the study of vocal counterpoint derived from a sense of the relevance of such study for the writing of contemporary, as opposed to historical, music. In this regard, the eighteenth century differed fundamentally from the nineteenth in its relation to the stile antico, for the later era demonstrated a full-fledged historicism in the form of the Cecilian movement. $^{2}$

Eighteenth-century Vienna provides an ideal context for a discussion of the Palestrina style for two reasons. First, there existed in Vienna an unbroken tradition of performing music by Palestrina and other composers of the late sixteenth and early seventeenth centuries. Second, one of the preeminent figures associated with the stile antico during the eighteenth century, Johann Joseph Fux (1660-1741), worked in Vienna and in 1725 published his enormously influential

1. Karl Gustav Fellerer's Der Palestrinastil und seine Bedeutung in der vokalen Kirchenmusik des achtzehnten Jahrhunderts (Augsburg: D.B. Filser, 1929), still the most comprehensive study of the Palestrina style in the eighteenth century, regards the phenomenon as primarily one of imitation. (It frequently makes use of the expression Palestrina-Nachahmung.) An intent of the present article is to suggest a need for a revision of this point of view.

2. An important landmark in the early period of Cecilianism is E.T.A. Hoffmann's "Alte und Neue Kirchenmusik," which appeared in the Allgemeine Musikalische Zeitung, Jg. 16 (1814), columns 577-584, 593-603, and 611-619. The article is reprinted in E.T.A. Hoffmann. Nachlese, ed. Friedrich Schnapp (Munich: Winkler, 1981), 209-235, and is translated by Martyn Clarke as "Old and New Church Music," in E.T.A. Hoffmann's Musical Writings: "Kreisleriana," "The Poet and the Composer," "Music Criticism," ed. David Charlton (Cambridge, UK: Cambridge University, 1989), 353-376. For a broad range of primary writings related to Cecilianism see Winfried Kirsch, ed., Palestrina und die Idee der klassischen Vokalpolyphonie im 19. Jahrhundert: Zur Geschichte eines kirchenmusikalischen Stilideals (Regensburg: G. Bosse, 1989). 
Gradus ad Parnassum there. These circumstances helped to establish the important place of the Palestrina style in the contemporary musical life of Vienna and of geographical regions in close contact with the imperial city. The idiom both represented a living presence during the eighteenth century, not distantly historical in any way, and formed the most widespread basis for the training of composersand thereby enjoyed a broad applicability.

The survival of the stile antico long after it had ceased to be the dominant musical tongue owes much to a central feature of liturgical celebration: the prohibition against the performance of concerted works in church during the penitential seasons of Advent and Lent. This prohibition remained in force in the eighteenth century and ensured the continued familiarity of vocal polyphonic music. ${ }^{3}$ Thus, the stile antico possessed a functional character during this period and served as an adjunct to a set of specific external circumstances. This does not imply, however, that the Palestrina style lacked affective significance for eighteenth-century listeners, or that composers wrote in the style only when liturgical regulations demanded it. The example of the practice of setting particular sections of the Mass (e.g., Cum Sancto Spiritu, Et vitam venturi, and Dona nobis pacem) in vocal counterpoint demonstrates that practical considerations alone did not motivate composition in stile antico. The idiom conveyed multiple meanings, which will be demonstrated below.

Although all ecclesiastical institutions of Vienna observed the proscription against concerted music during Advent and Lent, one institution in particular, the imperial court chapel, cultivated its stile antico tradition to an exceptional degree. During the seventeenth century, the preparation of manuscript copies produced a large collection of vocal polyphonic works of the late Renaissance and early Baroque era in the chapel's archives. ${ }^{4}$ Composers from Rome-among

3. Contemporary documents confirming that a cappella works formed the principal music of worship during the penitential seasons include two records of liturgical music practices at the Viennese imperial court: Kilian Reinhardt's Rubriche Generali per le Funzioni Ecclesiastiche Musicali di tutto l'Anno of 1727 (A-Wn S.m. 2503) and Johann Andreas Ziss' Repertorium der von der Hofmusikkapelle aufgeführten Kirchenmusik of 1745-1756 (A-Wn Inv. I/ Hofmusikkapelle 15).

4. See Friedrich Wilhelm Riedel, Kirchenmusik am Hofe Karls VI. (1711-1740) (Munich and Salzburg: Katzbichler, 1977), 72-107. Riedel discusses a series of codices that were prepared mostly at the court of Emperor Ferdinand III (reigned 1637- 
them Palestrina, Giovanni Animuccia (c.1520-1571), and Gregorio Allegri (1582-1652) - are well represented in these copies. This connection possessed a political character, for the Viennese court saw in Rome a model of imperial and ecclesiastical might. The Eternal City's presence manifested itself in numerous spheres of Viennese life, among them music. ${ }^{5}$ The stile antico, firmly linked with the Vatican and especially with the Sistine Chapel, thus assumed significance as an important element of a general cultural tendency. As will become clear, the aspiration of the Habsburgs to establish a holy, universal empire has implications for our understanding of the meanings conveyed by the Palestrina style in eighteenth-century Vienna.

The artistic personality in whom the association between the court chapel and the classical vocal polyphony found its richest, most comprehensive expression was Fux, who served as imperial Kapellmeister from 1715 until his death in 1741. In fact, works in Palestrina style make up only a small portion of Fux's compositional output. ${ }^{6}$ His primary contribution to the stile antico tradition of eighteenth-century Vienna consists less of a body of music than of a compelling vision of a permanent, universal musical language that he transmitted by a variety of means. These means included specific compositions, of which the canonic Messa di San Carlo merits special note; however, the Gradus ad Parnassum formed a much more potent agent in the perpetuation of Fux's ideal. This seminal document of compositional pedagogy has made Fux's name virtually synonymous with the Palestrina mythos of the eighteenth century, as well as with the species method of teaching counterpoint. ${ }^{7}$ However, its full signifi-

$1657)$ and that remained in use well into the eighteenth century. Although he does not detail the provenance of all of the sources, the origin of a manuscript of Palestrina's hymns (A-Wn Mus. Hs. 16709) as a copy of the 1589 print of this music suggests the general manner in which the court acquired its repertoire of old polyphonic works.

5. Non-musical examples of the link between the two cities include Johann Bernhard Fischer von Erlach's church of St. Charles Borromeo, with its twin pillars modeled on the columns of Trajan and Marcus Aurelius, and the title of Holy Roman Emperor held continuously by the Habsburg ruling house since the fifteenth century.

6. This is true of every Viennese composer of the eighteenth century, with the single exception of Matteo Palotta (1688-1758), hired at Fux's recommendation for the express purpose of writing music in stile antico for the court.

7. Facsimile edition of the Gradus ad Parnassum by Alfred Mann in Johann Joseph Fux: Sämtliche Werke, VII/1 (Kassel: Bärenreiter, 1967). Section on species counterpoint translated by Mann as The Study of Counterpoint (New York: W.W. Norton, 1965.) Section on fugue translated in Mann, The Study of Fugue (New York: 
cance remains somewhat obscure, at least in the English-speaking scholarly world, because of its piecemeal transmission in abridged translations. ${ }^{8}$ The Gradus did much more than codify the rules of counterpoint; it articulated some of the principal attitudes of its age toward religion and music. A deeply pious and specifically Catholic outlook imbues the Gradus and motivates a striving toward the timeless:

Aloysius. I judge that no one could doubt that, just as sacred things are above worldly ones in dignity, so music offered up for divine worship, destined to last eternally, is much nobler than other music, and special care should be given to it. ${ }^{9}$

In this passage, Fux links sacred music with an everlasting quality ("destined to last eternally"). From a compositional perspective, such a quality takes the form of an adherence to objective principles that remain valid regardless of time, place, and prevailing stylistic fashion. Fux's concern in the Gradus with establishing the immutable laws of the art of music thus stems, to a large degree, from his faith. However, he certainly did not intend these laws to apply only to sacred music, the statement above notwithstanding. The Gradus did not serve as a training manual for church music composers only, but found general use among all composers. The ideal of timelessness adumbrated on the pages of the Gradus therefore embraces all of music, even as it reflects a strongly religious attitude. Indeed, it would be incorrect to assume an unequivocal division between sacred and secular styles in eighteenth-century Austria, where an atmosphere of devoutness colored spheres of culture and society other than those that constituted the sacred, narrowly defined. ${ }^{10}$

W.W. Norton, 1958), $75-138$. Concluding section translated by Susan Wollenberg in "Gradus ad Parnassum (1725): Concluding Chapters," in Music Analysis, 11 (1992), 215-243. Additional portions translated by Joel Lester in Between Modes and Keys: German Theory 1592-1802 (Stuyvesant, NY: Pendragon Press, 1989), 183-209.

8. This problem of reception forms the subject of a paper, "Fux's Gradus ad Parnassum and the Search for a Timeless Music," which I delivered at the seventeenth annual meeting of the New England Conference of Music Theorists in March 2002 in Boston, and which I am preparing as an article.

9. Gradus ad Parnassum, 242. Translation from Wollenberg, 217.

10. See Anna Coreth, Pietas Austriaca: Ursprung und Entwicklung barocker Frömmigkeit in Österreich (Vienna: Verlag für Geschichte und Politick, 1959). 
The ambition to codify the universal precepts of musical composition helps to account for the conspicuous presence in the Gradus of Palestrina, whose music Fux considered to exemplify these precepts perfectly. The relationship of the two figures is a far from straightforward one of unqualified admiration by the latter, however. At the outset of this essay, I asserted that a historicist impulse did not underlie the continued composition and performance of works in stile antico during the eighteenth century; yet the unrestrained praise of Palestrina that Fux sprinkles across the pages of the Gradus does seem to manifest a genuine historicism. The famous encomium, "The Prince of this style is undoubtedly Aloysius Praenestinus, that light of music, whom I advise you again and again to imitate," "l suggests that Fux regards an ability to reproduce an older style as one of the pupil's basic goals.

There exists a need to read between the lines of Fux's statements, however. A careful assessment of Palestrina's place in the Gradus must begin with a recognition of the striking absence of any quoted passages from the composer's works, a most curious circumstance given the exhortation "again and again to imitate." Indeed, following this exhortation, Fux provides a series of illustrative examples from his own music, not Palestrina's. ${ }^{12}$ He could easily have acquainted the student of the Gradus with some of Palestrina's compositions; as imperial Kapellmeister, he played a leading role in maintaining the regular performance of works by the Roman master and his contemporaries. Yet Fux bypasses his hero, even as he adulates him.

I suggest that Fux subtly exploits the powerful mystique associated with Palestrina in order to impart authority to his own understanding of the nature of musical composition. The dialogue format of the Gradus, with Aloysius-Palestrina as master and Josephus-Fux as student, creates an authorial distance by implying that Fux's ideas in fact originate with the great sixteenth-century composer. The endearing characterization of Josephus as an eager pupil, anxious to receive wisdom from his revered teacher, enhances the pretense; Fux felt a necessity to deploy the most potent resources in the advocacy

11. Ibid., 243. Translation from Wollenberg, 219. Aloysius Praenestinus was one of the most common forms of the composer's name used in his lifetime.

12. The cited works are the Missa Vicissitudinis, the Missa In fletu solatium, the Missa Credo in unum Deum, the offertory Ad te Domine levavi, and the motet Ave Maria. 
of his views, evidently because of their contested nature. His own elevated status as Kapellmeister of the imperial court, the most prestigious musical post in the Habsburg lands, did not suffice. Hence, he called into action, as it were, an even more commanding figure in eighteenth-century musical culture: Palestrina. The exalted title of "lawgiver" with which Josephus at times addresses Aloysius enforces a sense that the assertions of the Gradus stem from a voice of absolute, indisputable truth. Given the contrivance of the dialogue format, Fux in effect calls himself a lawgiver, thus suggesting the degree of conviction and passion (not to speak of immodesty) with which he held his opinions.

The preface of the Gradus (one of the few sections not in dialogue, in which the author assumes his own persona) contains the following vivid assertions:

[M] usic has become almost arbitrary and composers refuse to be bound by any rules and principles, detesting the very name of school and law like death itself.

I shall not be deterred by the most ardent haters of school, nor by the corruptness of the times.

I do not believe that I can call back composers from the unrestrained insanity of their writing to normal standards. ${ }^{13}$

Fux here attacks unspecified contemporaries for their callous disregard of fundamental principles. He thereby gives expression to his belief that a conformity with such principles constitutes the essential quality of truly good music. Fux's aspiration to provide a definitive statement on the nature of a musical language grounded in unchanging and immutable laws undoubtedly motivated the publication of the Gradus. This aspiration reveals his universalist mindset, with its strongly Roman Catholic flavor. The notions of divine, everlasting empire that so shaped the sociopolitical character of early eighteenthcentury Vienna prompted an effort to cultivate a music that transcended the bounds of time and place. This endeavor found an ideal starting point in Palestrina.

For Fux, the works of Palestrina furnished the material from which he could distill a set of abstract precepts of composition. Their classi-

13. Translations from Mann, The Study of Counterpoint, 17. 
cal lucidity and refinement underscored a stylistic manner that deemphasized elements of individuality in favor of an impersonal objectivity. Although such an understanding of Palestrina's art failed to take into account its unique and idiosyncratic aspects, a more comprehensive knowledge of the composer's music did not interest Fux, as it did not serve his aims. The absence of any citations of Palestrina in the Gradus illustrates the lack of concern with representing the precise details of a specific idiom. Fux turned his attention instead to the usefulness of the broader features of the idiom for developing principles to be applied to contemporary music..$^{14}$ By means of these principles, he sought to inculcate "normal standards" in young aspiring composers. (For his contemporaries he apparently held out little hope.)

To this end, the Gradus promotes the view that there exist timeless verities of musical art that transcend the contingencies of individual artistic personalities. Fux favors a rational, systematic approach to composition over one based on emotional subjectivity and inspiration. In his effort to define a universally valid musical language, he discusses the Palestrina style in such a manner as to avoid linking the idiom with a particular time and place. ${ }^{15}$ Because temporal and geographical specificity is an essential prerequisite of historical think-

14. Thus the following criticism by Fellerer of Fux's compositions in strict style misses the point: "When we observe Fux's works in the old style, we find that he experienced relatively little success in imitating it strictly. This realization stands in opposition to the great significance that has always been attributed to Fux [i.e., as a representative of the old style], and to the influence that he exerted upon a cappella composition in German-speaking lands" ("Betrachten wir Fuxens Werke im alten Stil, so finden wir, dass es ihm verhältnismässig wenig gelungen ist, diesen streng nachzuahmen. Diese Erkenntnis steht im Widerspruch zu der grossen Bedeutung, die Fux stets zugemessen wurde, und zu dem Einfluss, den er auf die a cappellaKomposition in Deutschland ausübte." Der Palestrinastil, 295). Indeed, Fellerer evaluates a broad selection of works according to the degree to which they adhere to the characteristics of their sixteenth-century model (which characteristics are therefore minutely detailed in a long preliminary section of the monograph, 37-80). However, to account for the circumstance that the purported attempts at imitation rarely succeeded, he introduces the implausible notion of Nachahmen-Wollen, as if a gap between aim and realization were caused by deficient mimetic skills on the part of the great majority of eighteenth-century composers.

15. Joel Lester writes, "A final aspect of Gradus that has enhanced its status as a pedagogic classic is its relative abstraction from any particular compositional style." See his Compositional Theory in the Eighteenth Century (Cambridge, MA: Harvard University Press, 1992), 34. 
ing, the absence of such specificity in the Gradus indicates the inappropriateness of regarding Fux as historicist in outlook. Palestrina did not matter to him as an individual composer of late sixteenthcentury Rome; he mattered as a paradigm, an idealized model of voice-leading purified of the unpredictable, haphazard aspects of personality.

This understanding of music, perhaps revealing some debt to preHumanist attitudes, ${ }^{16}$ evidently came under increasing challenge in Austria during the early eighteenth century. Fux felt impelled to criticize a contemporary obsession with novelty, originality, and idiosyncrasy, thereby hinting at the growing importance of these qualities. He especially abhorred a trend toward the glorification of individual musicians, directing some of his most colorful polemic at opera singers in particular. ${ }^{17}$

Fux's passionate belief in the supremacy of rational principles over personal subjectivity emerges most clearly in a brief but strategically located section of the Gradus titled "De Gustu." This section occurs immediately before the concluding discussion of the different styles of composition, which represents Parnassus, the point at which the pupil is no longer writing exercises but actual music. Prior to the final ascent, as it were, Fux ensures that the pupil properly understands the nature of taste, which will necessarily play a significant role in his future work. The popular idea that taste cannot submit to judgment (e.g., "I know what I like" and "Taste is not a matter for argument") comes under pointed scrutiny. Aloysius relates an anecdote in which a man prefers the croaking of frogs to the singing of nightingales. When asked what he thinks of this preference, Josephus responds in comic understatement: "I think it not undeservedly calls for some criticism." ${ }^{18}$ Objective measures do exist for evaluating taste, which therefore does not belong exclusively to the realm of opinion.

16. See Gary Tomlinson, Monteverdi and the End of the Renaissance (Oxford, Oxford University Press, 1987), 3-30, for an excellent discussion of the contrasting worldviews of Humanism and Scholasticism.

17. "Even greater censure and derision are due to those musicians who, even though they are endowed with no talent, twist their face into a thousand forms, so that not even a harlequin's masks are so varied, and in place of one note they produce nearly five sounds at once. Indeed, this folly goes so far that some engage in a rivalry for their own glory, in which the victory is granted to the swirling notes and neither the music nor the text is perceived." Gradus ad Parnassum, 220. Translation from Lester, Between Modes and Keys, 188. 
The values that define the Gradus lie at the heart of the legacy of Fux's work to later generations, as much as the lucid explication of the rules of counterpoint. The extraordinary success enjoyed by the work during the eighteenth century demonstrates that an approach to composition predicated on rational, systematic study remained important, even as notions of inspiration and individual genius became increasingly influential. Strict counterpoint embodied a paradigm of music as a craft, requiring diligence and respectful adherence to its fundamental laws. This paradigm maintained its relevance in a pluralistic musical culture characterized by the coexistence of competing ideals. It helps to explain the role played by the Gradus in shaping the practice of eighteenth-century Viennese composers, few of whom wrote significant numbers of works in stile antico once past their period of training. The careers of two of these composers, Georg Christoph Wagenseil (1715-1777) and Antonio Salieri (1750-1825), provide particularly instructive examples.

Wagenseil and Salieri, like so many others during the eighteenth century, received an education that had its basis in the Gradus. Wagenseil, in fact, studied with Fux himself and also with Fux's colleague, Matteo Palotta, during the 1730 s. He deeply impressed the imperial Kapellmeister with his remarkable fluency in the stile antico. ${ }^{19}$ Indeed, Fux believed that Wagenseil would perpetuate his legacy of a serious contrapuntal style, ${ }^{20}$ not foreseeing that his pupil would take a very different turn in his future professional activities. Still, Wagenseil carried on the tradition of the stile antico by training his

18. Ibid., 239. Translation from Wollenberg, 215.

19. Wagenseil's most substantial stile antico composition is the early Missa a quattro da Capella, probably written during the 1730 s. I am currently preparing an edition of this work as part of the forthcoming volume, Three A Cappella Masses, Eighteenth-Century Vienna, Wagenseil, Reutter, Hofmann, to be published by A-R Editions (Middleton, WI). See Example 1 for its opening measures. I discuss a number of Wagenseil's smaller works in strict style in my doctoral dissertation, The Tradition and Ideal of the Stile Antico in Viennese Sacred Music, 1740-1800 (Harvard University, 2000), 111-131.

20. See Daniel Heartz, Haydn, Mozart and the Viennese School, 1740-1780 (New York: W.W. Norton, 1995), 89.

21. Johann Baptist Schenk, "Autobiographische Skizze," in Studien zur Musikwissenschaft 11 (1924), 75-85; trans. Paul Nettl in Forgotten Musicians (New York: Philosophical Library, 1951), 265-279. 
own students in the idiom. ${ }^{21}$ Salieri studied principally with Florian Leopold Gassmann (1729-1774), ballet composer and later Kapellmeister (serving 1772-1774) at the imperial court. As was the case with Wagenseil, the Gradus formed the core of the lessons for the young Italian. He wrote his first large-scale composition, the highly accomplished Missa stylo a capella, at the age of 17; this work represented a most impressive debut. ${ }^{22}$

Although both Wagenseil and Salieri attained a high degree of proficiency in the Palestrina style, neither revealed a continued interest in writing music in this idiom. Instead, both concentrated on approaches to composition that, on the surface, have little to do with the stile antico. Wagenseil made a substantial contribution to the development of a modern style of Viennese instrumental music, whereas Salieri became one of the preeminent Viennese composers of opera. Thus, in neither case did their early training, which centered around study of vocal polyphony, determine the direction of their mature work. The pattern of their careers demonstrates in a vivid manner that mastery of strict counterpoint formed an essential preliminary stage in the path toward achievement in free composition. Such mastery indicated the acquisition of fundamental technical equipment needed to write "real" music. It evidently served as a credential, a proof of compositional readiness, as it were. Salieri's Missa stylo a capella furnishes but one example of this kind of proof. Wagenseil, Leopold Hofmann (1738-1793), and Joseph Haydn all wrote Masses in stile antico as young men (see Examples 1 and 2 for the opening passages of the first two, unpublished works) ${ }^{23}$; in each case except Haydn, the Mass was the composer's first and was written before he had reached 25 years of age. ${ }^{24}$

22. Editions of this Mass have been prepared by Otto Biba (Altötting: Alfred Coppenrath, 1987) and Jane Schatkin Hettrick (Vienna: Doblinger, 1993).

23. Hofmann's Missa alla Capella of circa 1760 will appear as part of the aforementioned volume, Three A Cappella Masses, Eighteenth-Century Vienna. Haydn's recently rediscovered Missa Sunt bona mixta malis dates from 1768 and is available in an edition by H.C. Robbins Landon and David Wyn Jones (Paris: Mario Bois, 1992). Wyn Jones discusses this fragmentary work in his article "Haydn's Missa Sunt Bona Mixta Malis," Music in Eighteenth-Century Austria, ed. David Wyn Jones (Cambridge, UK: Cambridge University, 1996), 89-111.

24. The relatively few composers who showed an affinity for the stile antico as older artists include Fux, Johann Georg Albrechtsberger (1736-1809), and Michael Haydn (1737-1806). 

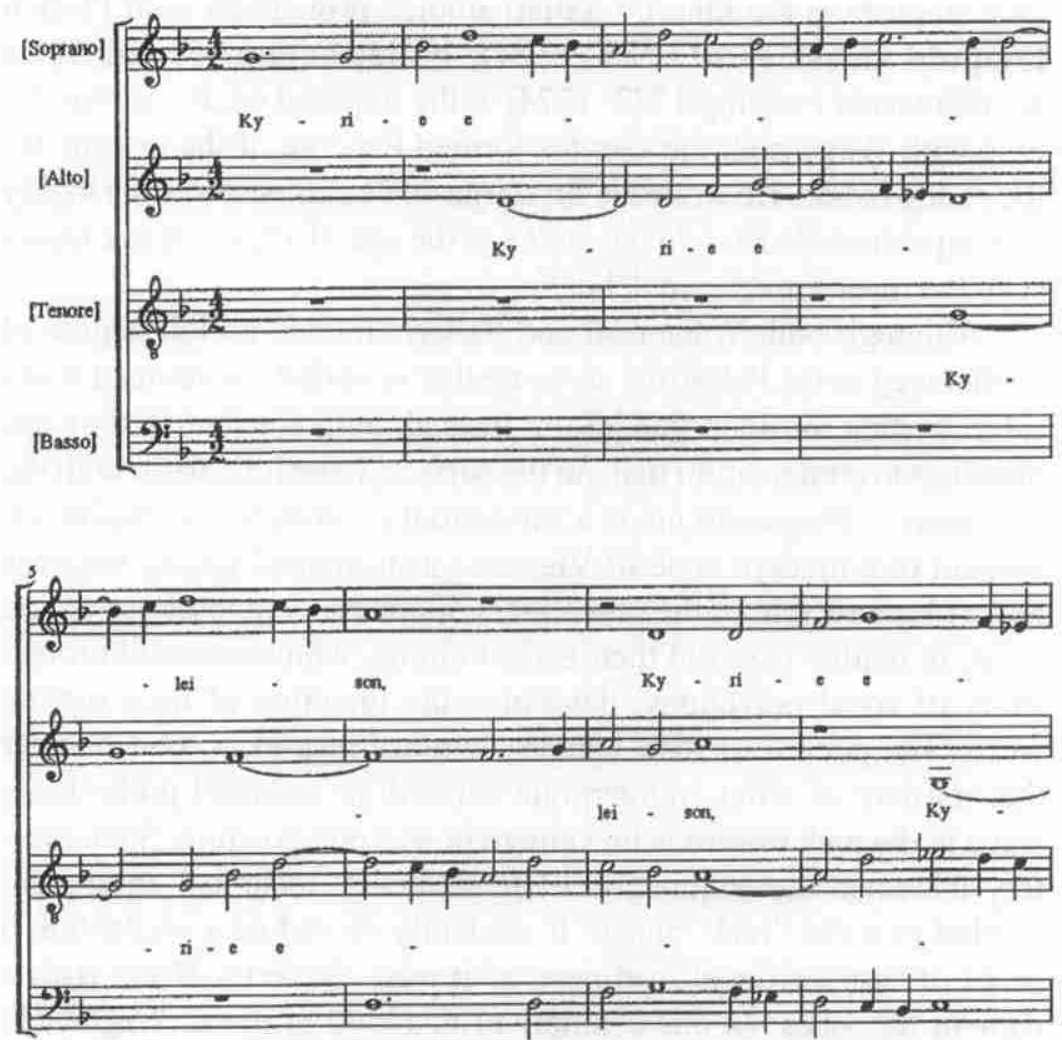

Ky $\quad$ ri * e + lei - san,

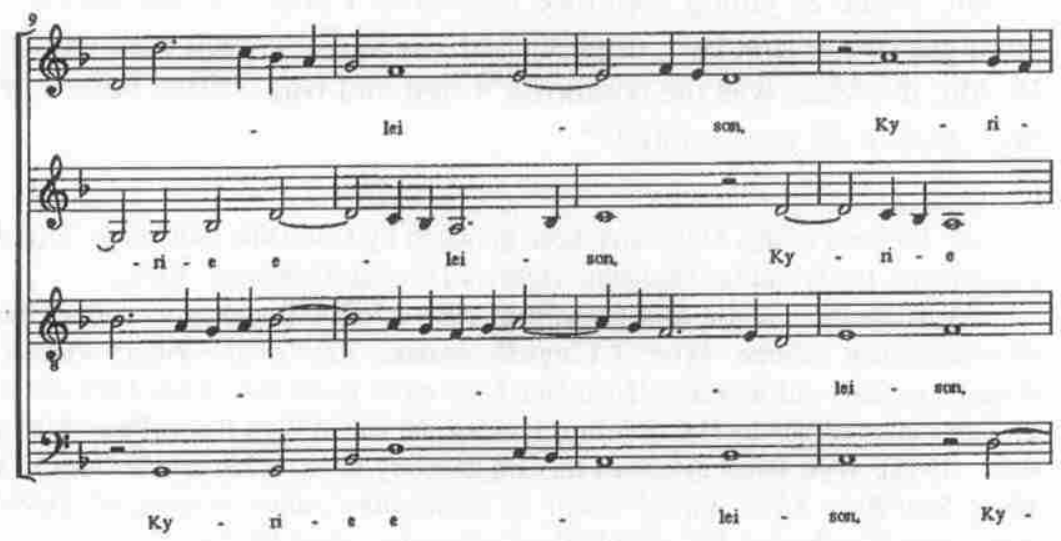

Example 1. Georg Christoph Wagenseil, Missa a quattro da Capella, Kyrie, mm. 1-12. 

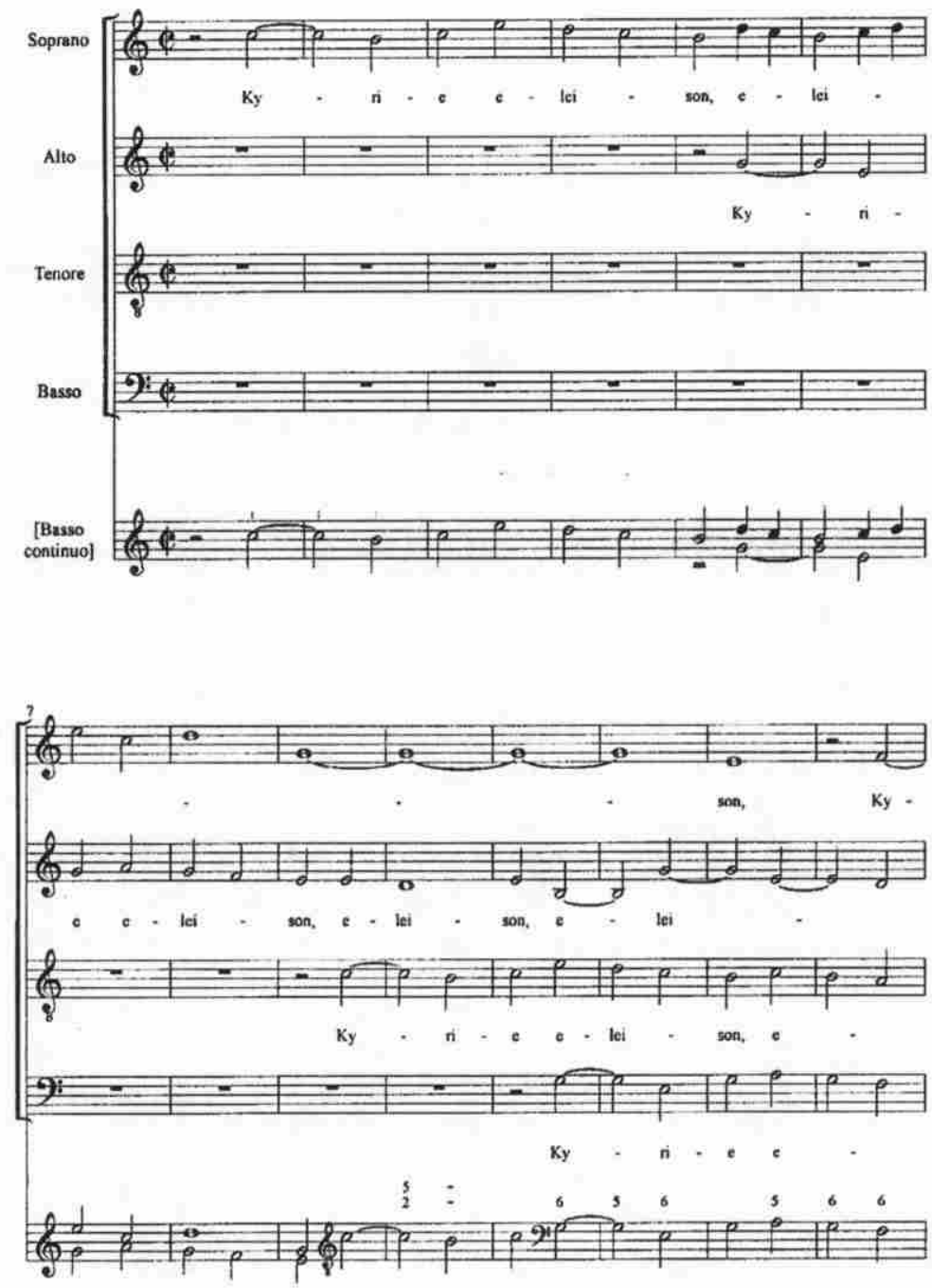

Example 2. Leopold Hofmann, Missa alla Capella, Kyrie, mm. 1-14.

Thus, in eighteenth-century Vienna, strict counterpoint did not represent an end in itself. Rather, the principles it embodied provided a structural undergirding for works in free style. From this point of view, an analysis of the relationship between strenger Satz (strict composition) and freier Satz (free composition) forms one of the crucial tasks for historians of eighteenth-century music. The present es- 
say can only suggest some approaches for future research on a topic of such wide scope (in other words, it can only act as a mere gradus to a Parnassus).

Of primary importance is a recognition that no absolute boundary existed between antico and moderno categories. ${ }^{25}$ One therefore cannot neatly separate eighteenth-century works into these two style groups. Because of the nature of its interaction with free composition, strict counterpoint exerted an influence on music as a whole. In a broad sense, the eighteenth-century Viennese repertoire in its entirety represents a generalized manifestation of the stile antico. The identification of a composition as unequivocally antico or moderno, then, does not accord with the essential nature of style during this period; the labels form only the theoretical poles of a spectrum in the middle of which lay the great majority of music. I have used the expression "work in stile antico" thus far primarily out of linguistic convenience; it denotes a piece that demonstrates the outward char-

25. The duality of idioms that originated around 1600 served varying purposes during different periods of subsequent music history. In the seventeenth century, it helped to articulate the opposing viewpoints in the controversies surrounding the rise of the new expressive style in Italy at the start of the century. Proponents of this style formulated the dichotomy as a response to criticisms that the modern music did not conform to established rules of composition, challenging the very premise of these criticisms by suggesting that their work was governed by a wholly new set of principles (called seconda prattica by Giulio Cesare Monteverdi). Thus, the dichotomy constituted a defense of an aesthetic position. One finds another example of this use of the opposition of idioms in Marco Scacchi's Breve discorso sopra la musica moderna (1649), in which occurs one of the first instances of the specific terminology stile antico and stile moderno. For a detailed discussion of the stile antico in the seventeenth century, see Stephen R. Miller, Music for the Mass in Seventeenth-Century Rome: Messe piene, the Palestrina Tradition, and the Stile antico (Ph.D. dissertation, University of Chicago, 1998). By the eighteenth century, when the new style had long achieved ascendancy and its advocacy was no longer required, the dichotomy took on a changed character (although some commentators still felt an urge to express a marked preference for the stile moderno; e.g., Johann Mattheson's rather unfavorable characterization of "Moteten-Styl" in his Der vollkommene Capellmeister of 1739,74$)$. It became concerned more with the continuing need for a cappella music in the celebration of liturgy during the penitential seasons. This practical orientation accounts for the common use of the expression A-Cappella Stil to identify the stile antico during this period. With little further need to maintain a sharp polarization of styles to justify the validity of one of them, the distinction between antico and moderno idioms began to diffuse. I would like to thank Stephen Miller for a personal communication on this matter. 
acteristics of strict writing to more than the usual extent. A comprehensive study of the Palestrina style thus must include examination of a broad variety of compositions, and not just those that obviously are "in stile antico."26

If the progression from a manifestly antico manner to one that subsumes the principles of vocal polyphony within the elaborations of free style constitutes a basic facet of compositional training in eighteenth-century Vienna, the specifics of this progression remain somewhat obscure. The Gradus ad Parnassum provides a few hints, although it hardly offers sufficiently detailed discussion to permit modern historians an intimate understanding of how exercises in species counterpoint equipped one to write operas, symphonies, and sonatas. The absence of such detailed discussion is perhaps a weakness of Fux's work, although numerous eighteenth-century composers successfully managed the transition without close guidance. Repeated mechanical practice in the techniques of strict counterpoint undoubtedly resulted in an internalization of these techniques, which acted as an ever-present background influence on later compositional efforts. Yet one should not assume that the transformation of style occurred in a more or less automatic fashion, or that it did not involve a concrete set of pedagogical procedures. A more precise understanding of this matter requires further detailed investigation of the study of composition in the eighteenth century. This topic forms an especially crucial area of research, for it touches on the fundamental nature of musical language during this period. ${ }^{27}$

26. Carl Schachter's superb analysis of Frédéric Chopin's Prelude in E minor ("Schenker's Counterpoint," Musical Times [1988], 524-529), although a discussion of a nineteenth-century work, can serve as a model for the kind of investigation proposed here. Schachter convincingly demonstrates that the diatonic voice-leading principles of strict counterpoint provide a controlling framework for the pervasive chromaticism of Chopin's music.

27. I suggest the music of Mozart as a convenient starting point for a thoroughgoing consideration of this matter, because of the ready availability and familiarity of his works and because he is a composer whose relation to the stile antico is welldocumented yet who wrote very few compositions in strict style. Mozart's sacred music in particular furnishes many excellent examples of a clear influence of vocal counterpoint on free writing. A suggested repertoire for study includes the Miserere nobis, K. 85/73s and the antiphon Quaerite primum regnum Dei, K. 86/73v (Mozart's most manifestly antico pieces, written as a test of contrapuntal skill for Padre Martini in Bologna in 1770); the Pignus futurae of the Litaniae de venerabili altaris 
In the closing section of the Gradus, Fux suggests that species counterpoint and free composition relate as background and foreground. The section contains a survey of contemporary styles, and for the first time the pupil confronts the challenge of comprehending the principles he has mastered thus far within the framework of actual music. ${ }^{28}$ The challenge quickly comes to the fore, as an attentive Josephus several times notes apparent violations of the rules of strict writing in passages shown him by Aloysius. In each instance, Aloysius explains the violations as diminutions of voice-leading structures that adhere to the precepts of vocal counterpoint. For example, when Josephus points out the incorrect 7-8 and 2-1 resolutions of a series of suspensions in an excerpt from Fux's Missa Credo in unum Deum, Aloysius presents a reductive analysis that reveals the underlying 7-6 and $2-3$ resolutions (see Example 3 ). ${ }^{29}$

Fux here reveals an affinity with a strain of theoretical thought, extending some three hundred years from Christoph Bernhard to Heinrich Schenker, that posits a primary relationship between explicit detail and implicit structure. The work of Schenker, in particular, represents the most developed treatment of this relationship and furnishes a perspective from which to understand how the stile antico shaped even the most complex compositions of the common-practice era. ${ }^{30}$ In a sense, it supplies the crucial missing element of the Gradus, comprehensively explicating the notion of the essential identity of antico and moderno idioms that Fux had merely intimated. ${ }^{31}$ Of course, Schenker differed sharply from Fux in his abstract speculative orien-

Sacramento, K. 125; the Laudate pueri sections of the Vesperae solennes, K. 321 and K. 339; and the polyphonic a cappella movements of the Masses and the Requiem, K. 626, which most often occur as settings of specific text segments (a cappella refers here to colla parte instrumental accompaniment, rather than pure vocal sonority; see footnote 41). On the predominance of voices in the Requiem and a new, austere sacred style that Mozart began to develop in his last years, see Christoph Wolff, Mozart's Requiem (Berkeley and Los Angeles: University of California, 1994), $32-38$.

28. Gradus ad Parnassum, 243-279.

29. Ibid., 267-271.

30. Of particular relevance here is Kontrapumkt (Stuttgart, Berlin, and Vienna: Universal Edition, 1910-1922), the second part of the Neue musikalische Theorien und Phantasien. The work has been translated by John Rothgeb and Jürgen Thym as Counterpoint (New York: Schirmer, 1987).

31. See Hellmut Federhofer, "Fux's Gradus ad Parnassum as Viewed by Heinrich Schenker," in Music Theory Spectrum 4 (1982), 66-75. 

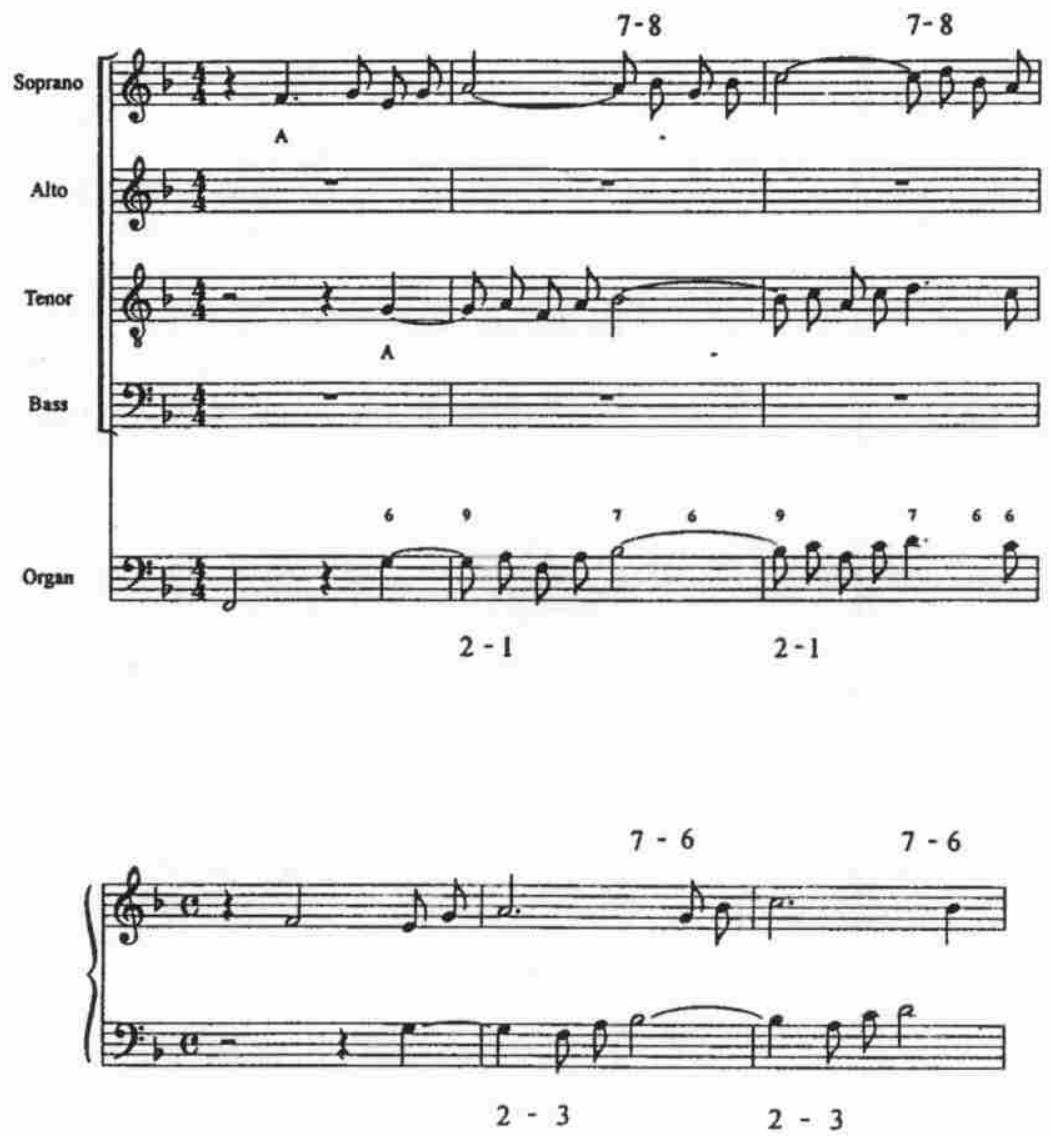

Example 3. Johann Joseph Fux, Missa Credo in unum Deum, opening of Amen fugue (Credo), with analytical reduction.

tation, and even if he came to believe that his theories formed an absolute measure for judging the artistic quality of musical works, these theories cannot be used to train composers. Thus there remains the important question of how composers accomplished the shift from strict to free writing.

\section{SELECTED COMPOSITIONS}

In the remainder of this article, I offer analyses of selected compositions that I hope will suggest directions for a more wide-ranging exami- 
nation of the Palestrina style in eighteenth-century Vienna. I shall discuss three works: the Messa di San Carlo of 1719 by Fux, the Missa a capella of circa 1750 by Georg Reutter, Jr. (1708-1772), and the undated Missa in C by Johann Georg Albrechtsberger (17361809). ${ }^{32}$ These works illustrate a transformation in the harmonic language of the stile antico from modality to tonality that occurred during the middle decades of the century. ${ }^{33}$ Although Fux and his contemporaries showed little interest in imitating Palestrina, their music in stile antico preserved the modality that formed the basis for the linear-diatonic quality of the classical vocal polyphony. In the generation following Fux's death, however, composers assimilated tonality into the idiom, thereby adding a strongly vertical element to a still essentially linear style. ${ }^{34}$ This process of updating helped to ensure the continuing relevance of the principles of strict counterpoint.

Fux's Messa di San Carlo, a canonic Mass, undoubtedly represents one of the highest achievements of polyphonic writing in eighteenth-century Vienna. ${ }^{35}$ This Mass has done much to establish its composer's reputation as a quintessential master of the stile antico, although, in fact, it does not typify his output. Its title refers to the Tridentine reformer St. Charles Borromeo (1538-1584). This asso-

32. Fux's Messa di San Carlo is number 7 in Ludwig von Köchel's thematic catalogue of Fux's works, which appears in his biography, Johann Joseph Fux (Vienna: A. Hölder, 1872); the Mass is edited by Johannes Evangelist Habert and Gustav Adolf Glossner in Denkmäler der Tonkunst in Österreich, i/1 (Vienna: Artaria, 1894), a volume that also contains Fux's Missa SS. Trinitatis, Missa Quadragesimalis, and Missa Purificationis. Reutter's Missa a capella is number 6 of the Masses in the catalogue in Norbert Hofer's Die beiden Reutter als Kirchenkomponisten (Ph.D. dissertation, University of Vienna, 1925). Albrechtsberger's Missa in C carries the designation A.II.2 in the catalogue in Dorothea Schröder's Die geistlichen Vokalkompositionen Johann Georg Albrechtsbergers (Hamburg: K.D. Wagner, 1987); the sources listed by Schröder for the work include a manuscript located in the archives of Göttweig Abbey in Lower Austria that is, in fact, a copy of a different Mass by the composer (A.II.6 in Schröder's catalogue).

33. I discuss this transformation in greater detail in my The Tradition and Ideal of the Stile Antico, 91-251.

34. See chapter 7 (pp. 175-192) of Lester's Compositional Theory in the Eighteenth Century, which is titled "Harmonic Perspectives on Counterpoint."

35. The full title of the work as it appears in the beautiful dedication copy for Charles VI (A-Wn AN. 33. B. 74) is "Messa di San Carlo Per Musica Tutta in Canone e particolarmente diversificata." 
ciation enhances the status of the work as a locus classicus of strict composition, given the role played by Borromeo in the movement toward a simpler, more austere sacred music. The Mass forms a kind of parallel to Johann Bernhard Fischer von Erlach's monumental Church of St. Charles Borromeo in Vienna, a structure conceived in thanks for deliverance from a plague of 1713 and not completed until the closing years of the reign of Charles VI, ${ }^{36}$ The evocation of Rome in the twin pillars of the church, for which the columns of Trajan and Marcus Aurelius served as model, strengthens the link with a prominent figure of Vatican history. However, these pillars allude more directly to Emperor Charles, as they specifically symbolize Classical rather than Catholic Rome and thus embody the temporal, political component of the Habsburg notion of holy empire. The church as a whole offers a dual representation of power, as does the Messa di San Carlo. Fux dedicated the work to his employer, taking advantage of the shared name between Tridentine ecclesiastic and Habsburg monarch to highlight the combined sacred and imperial aura of the Palestrina style. ${ }^{37}$

Fux realizes his contrapuntal ambitions through a canonic structure in which the interval of imitation gradually shrinks from a ninth to a second (see Figure 1). This structure occupies the first half of the Mass, through the text "passus et sepultus est" at the end of the Crucifixus section of the Credo. In the remainder of the Credo, Fux reprises the intervallic compression at an accelerated pace, then extends it one step further to a unison for the conclusion of the movement. The compression recurs once more in the Agnus Dei, although here it covers only the intervals from a ninth to a fourth.

An analysis of the opening Kyrie of the Mass serves to illustrate the modality of Fux's music (Example 4). This Kyrie presents a double canon in which the alto imitates the bass at a ninth above while the tenor imitates the soprano at a ninth below. The initial five measures feature an alternation of the triads built on scale degrees 2 and 1, D

36. See Riedel, Kirchenmusik am Hofe Karls VI., 9-10, 51; and Paul NarediRainer, "Johann Bernhard Fischer von Erlach und Johann Joseph Fux: Beziehungen zwischen Architektur und Musik im österreichischen Barock," in Barock-regionalinternational, eds. Götz Pochat and Brigitte Wagner (Graz: Akademische Druckund Verlagsanstalt, 1993), 275-290.

37. The florid dedication in Italian in the dedication copy is reproduced on p. 65 of the aforementioned edition of the Mass in the DTÖ. 
Only canonic voices are indicated below, but other voices frequently participate in noncanonic imitation of canonic subjects.

Kyrie

Kyrie 1

B-A: $9^{\text {th }}$ above, S-T: $9^{\text {th }}$ below

Christe

B-A: $8^{\text {ve }}$ above, T-S: $8^{\text {ve }}$ above

Kyrie 2

S-T: $7^{\text {th }}$ below

Gloria

Et in terra pax

Qui tollis peccata mundi

Cum Sancto Spiritu

\section{Credo}

Patrem omnipotentem

Et incarnatus est

Crucifixus

Et resurrexit

Et ascendit

Et iterum venturus est

Et vivificantem

Qui cum Patre

Et unam sanctam catholicam

Confiteor

Et exspecto resurrectionem

Et vitam venturi

Sanctus

Sanctus

Osanna

Benedictus

Benedictus (3 voices)

Osanna da capo

Agnus Dei

Agnus Dei 1

Agnus Dei 2

Agnus Dei 3

Dona nobis pacem

S-A: $6^{\text {th }}$ below

B-T: $5^{\text {th }}$ above, A-S: $5^{\text {th }}$ above

T-A: $4^{\text {th }}$ above

A-S: $3^{\text {rd }}$ above, contrary motion

B-T: $3^{\text {rd }}$ above

B-T: $2^{\text {nd }}$ above, contrary motion; A-S $4^{\text {th }}$ above

T-S: $9^{\text {th }}$ above

B-A: $8^{\text {ve }}$ above

S-T: $7^{\text {th }}$ below

B-A: $6^{\text {th }}$ above

B-T: $5^{\text {th }}$ above

A-S: $4^{\text {th }}$ above

B-T: $3^{\text {rd }}$ above

S-A: $2^{\text {nd }}$ below

B-T: unison

B-T-A-S: $5^{\text {th }}$ above, $8^{\text {ve }}$ above, $12^{\text {th }}$ above

B-T-A-S: $4^{\text {th }}$ above, $8^{\text {ve }}$ above, $11^{\text {th }}$

above

S-A-T: $4^{\text {th }}$ below, $8^{\text {ve }}$ below

B-S: $17^{\text {th }}$ above, contrary motion

B-A: $9^{\text {th }}$ above

S-T: $8^{\text {ve }}$ below

B-A: $7^{\text {th }}$ above

B-T: $6^{\text {th }}$ above

B-T: $5^{\text {th }}$ above

B-T: $4^{\text {th }}$ above

Figure 1. Canons in Fux, Messa di San Carlo. In four-part canons the intervals of imitation from the leading voice are indicated. 

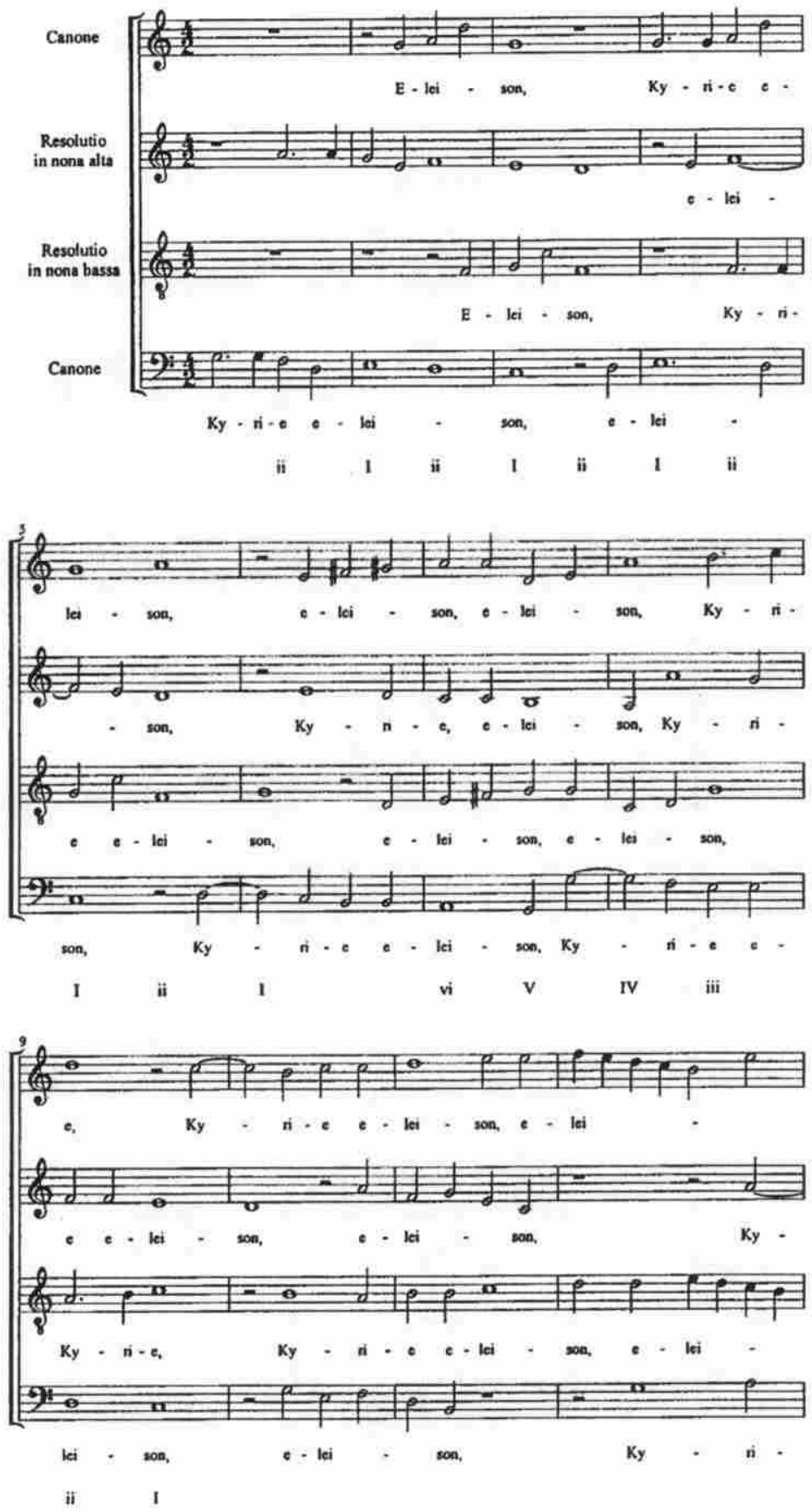

Example 4. Johann Joseph Fux, Messa di San Carlo, Kyrie I, mm. 1-12. 

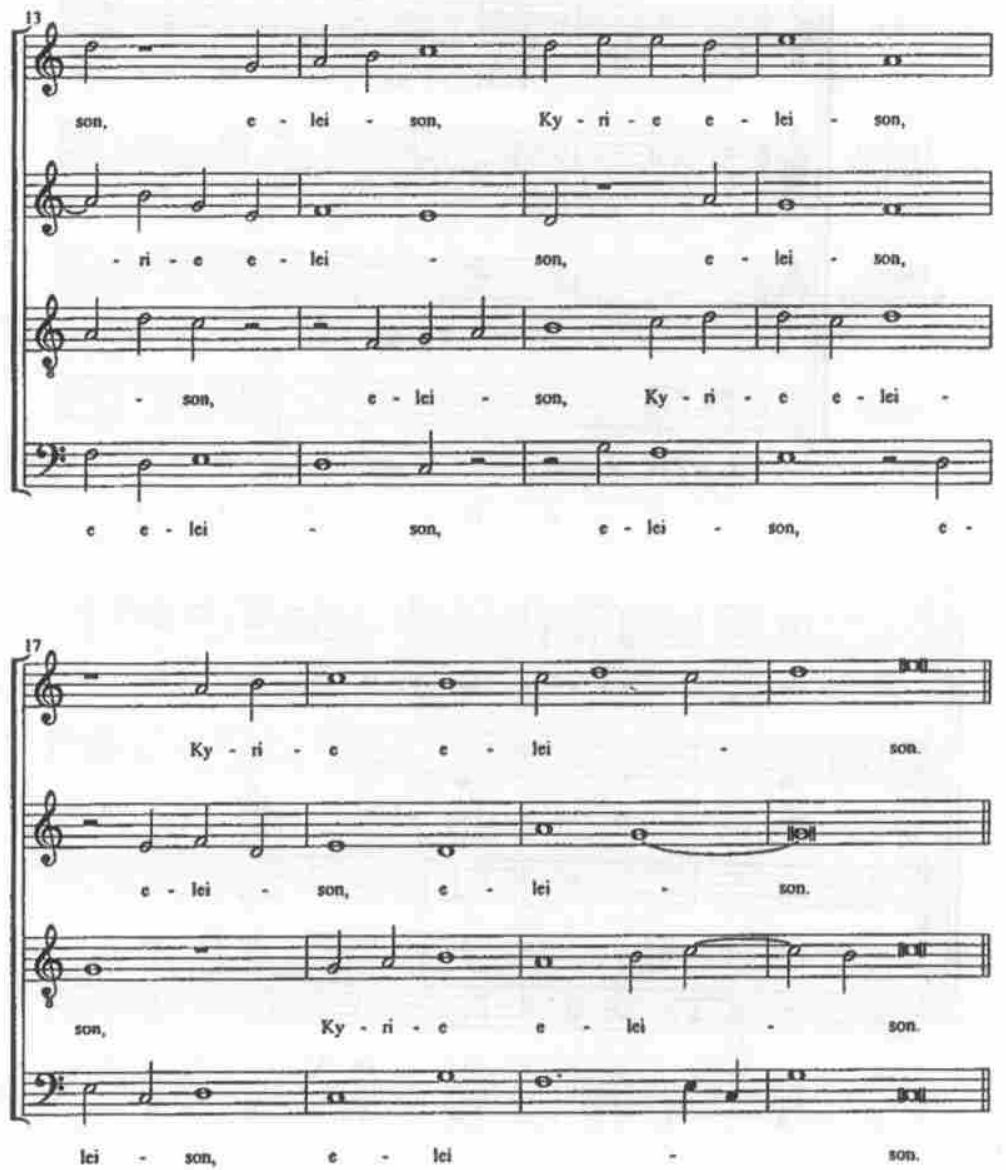

Example 4 (cont'd). Johann Joseph Fux, Messa di San Carlo, Kyrie I, m. 13 to end.

minor and $\mathrm{C}$ major. This static oscillation of adjacent harmonies, common in modal music, occurs rarely in tonal music because it compromises the directional thrust through the circle of fifths that defines the later system of pitch organization. Another progression uncharacteristic of tonality because of its weak sense of motion appears in measures 7 to 9 , which outline a linear descent through the triads of scale degrees 6 to 1 .

The remainder of the Kyrie possesses a somewhat more tonal flavor. An opposition of the triads of the tonic and the fifth begins to emerge here (as at measures 11 and 13), but it remains weakly articu- 
lated as the linearity enforced by the canonic counterpoint continues to prevail. Only in the final two measures, as the canon between bass and alto ceases (that between soprano and tenor continues to the very end), does a tonic-dominant polarity become manifest. This merely local effect serves to provide a firm closure to the movement.

Although the elaborate polyphonic edifice of Fux's music precludes the possibility of a developed functionality, one cannot make a generalization on the basis of this single example. The Missa a capella by Reutter, another canonic Mass but dating from approximately a generation after Fux, demonstrates that tonality could flourish even in this most rigorously contrapuntal of genres ${ }^{38}$ Indebted to its distinguished predecessor, the work reveals both a sense of tradition and a consciousness of contemporary musical style. Its opening Kyrie, like that of Fux's Mass, features a double canon (see Example 5 and the table in Figure 2). The character of the main subject provides a context for the unfolding of a tonally based language. This unlinear subject, an impossible one in Palestrina's true style, emphasizes the structural pitches of the tonic and the dominant in stressed rhythmic positions. It thus serves to announce the fundamental prin-

38. Hofer obliquely justifies his proposed date of composition of circa 1750 through a discussion in his dissertation that, in fact, mostly concerns the question of attribution (Die beiden Reutter als Kirchenkomponisten, 80-82). The sole surviving source of the work, a set of parts in the archives of Kremsmünster Abbey in Upper Austria (A-KR B 12, 312), gives the author as merely "Sig ${ }^{\circ}$ Reuter." The question thus arises whether the Mass is a composition by the identically named father (16561738) of the imperial Kapellmeister, a possibility that seems likely, given the music's retrospective character. To summarize briefly Hofer's argument: The two other stile antico Masses by a Reutter (numbers 3 and 4 in Hofer's catalogue) are securely attributed to the son, so that a vocal polyphonic idiom does not necessarily increase the probability of authorship by Reutter senior; furthermore, the treatment of double counterpoint and fugue found in the canonic Mass resembles that in two works that unquestionably derive from the pen of the younger Reutter, the double-chorus motet Fons Jesu misericordiae (Hofer 126) and a Salve Regina (Hofer 39). But if a decision in favor of the son seems reasonable, then Hofer evidently selects the approximate year of 1750 merely because it serves as a convenient midpoint of the composer's career, as he provides no evidence that helps to determine a more specific dating. In any case, Reutter's Mass is certainly a later work than Fux's Messa di San Carlo, and a provenance around the middle of the century accords with the increasing assimilation of tonality found in other stile antico compositions of the period. See, for example, David Wyn Jones's discussion of Reutter's Messa a 4. da capella (Hofer 4) of 1744, in "Haydn's Missa Sunt Bona Mixta Malis." 

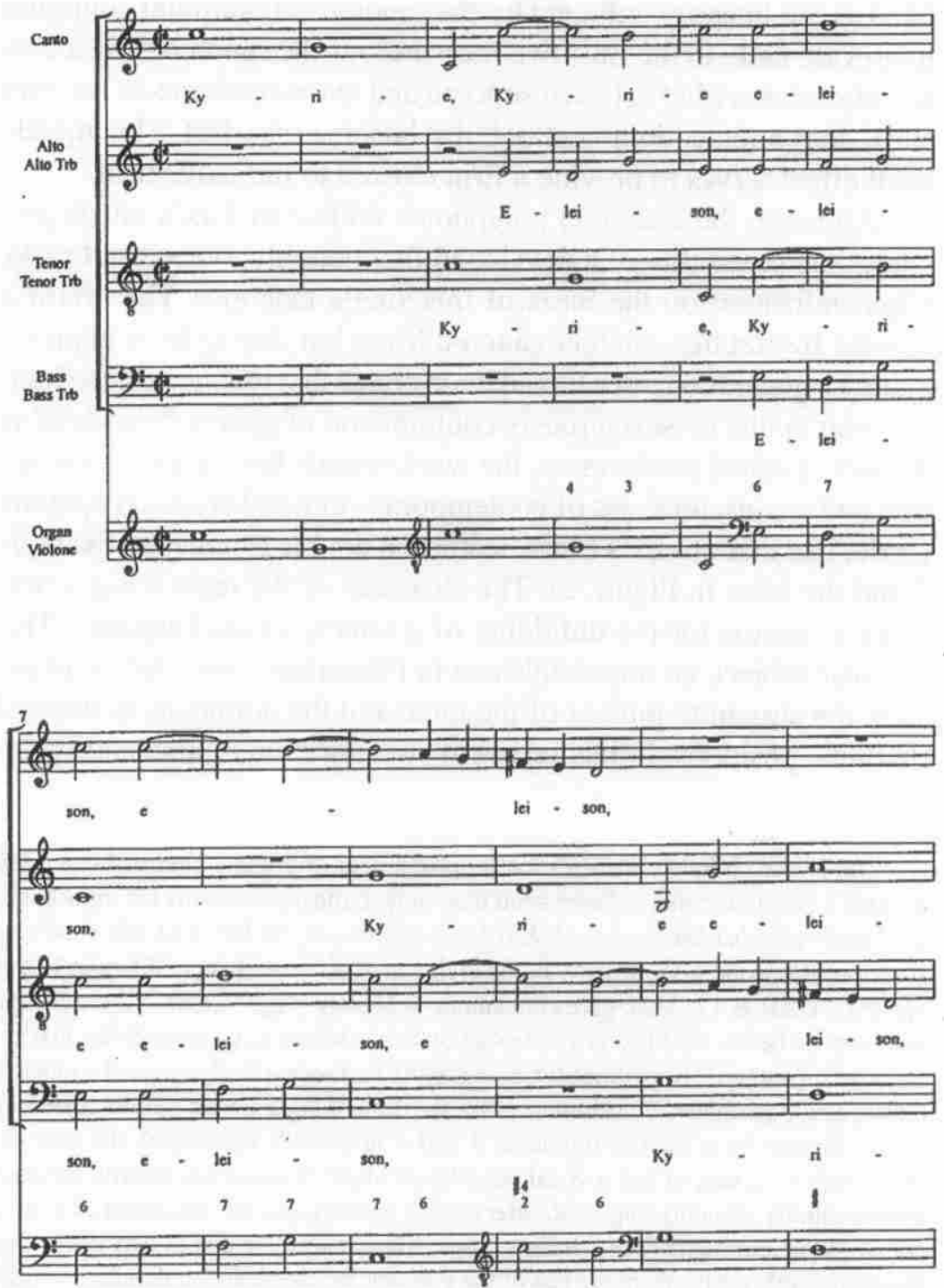

Example 5. Georg Reutter, Jr., Missa a capella, Kyrie I, mm. 1-12. 

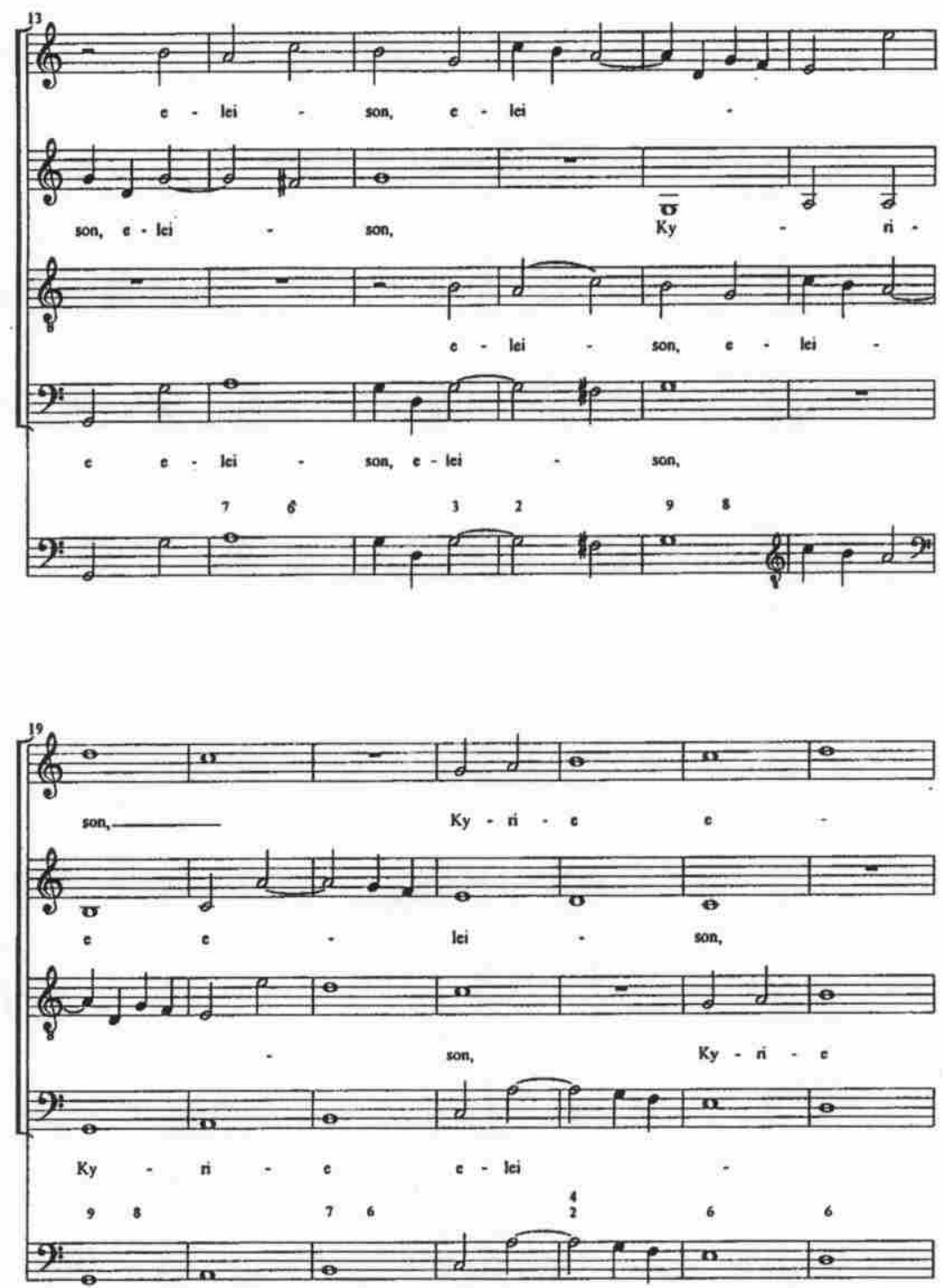

Example 5 (cont'd). Georg Reutter, Jr., Missa a capella, Kyrie I, mm. 1325. 

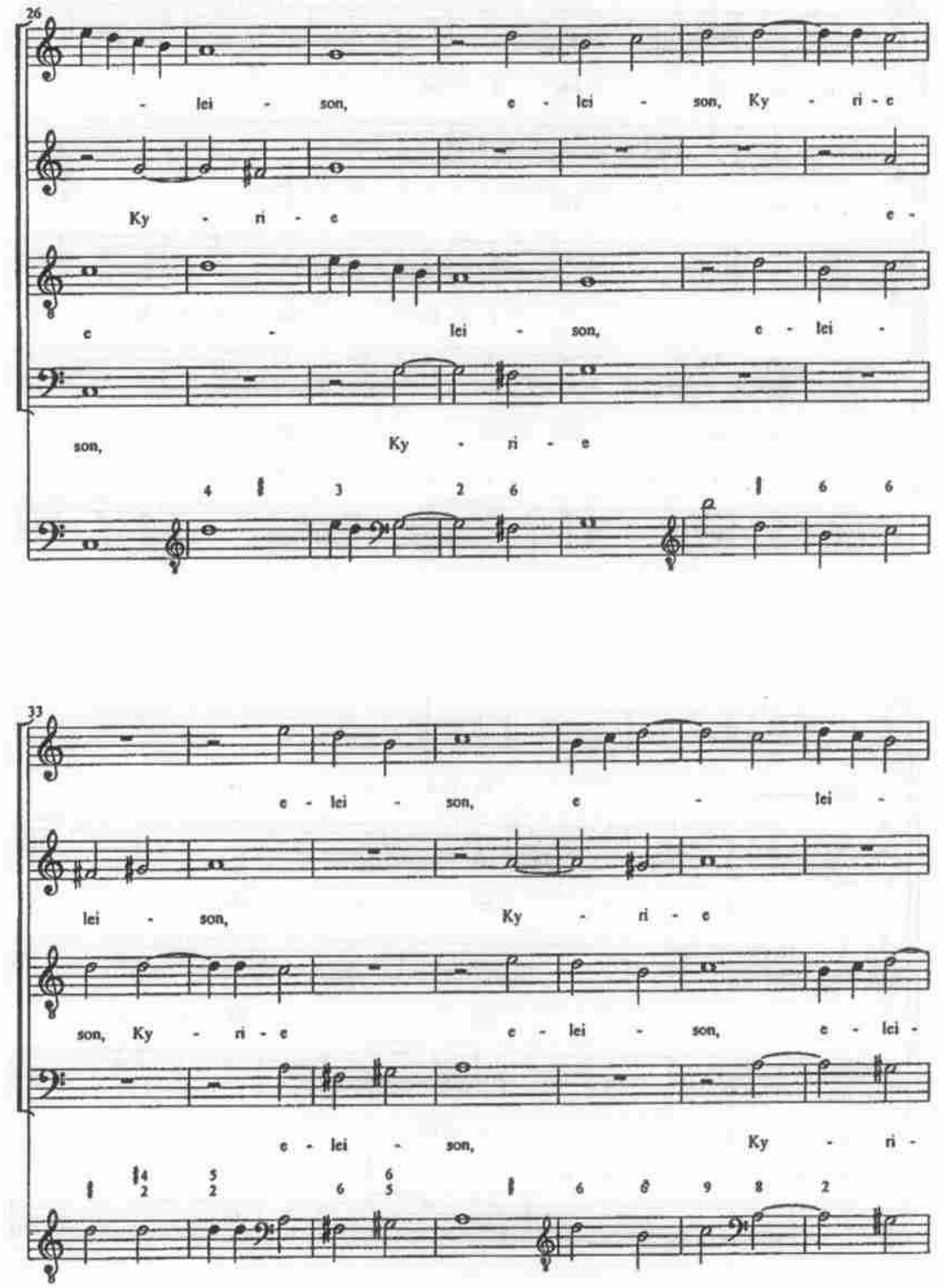

Example 5 (cont'd). Georg Reutter, Jr., Missa a capella, Kyrie I, mm. 2639. 

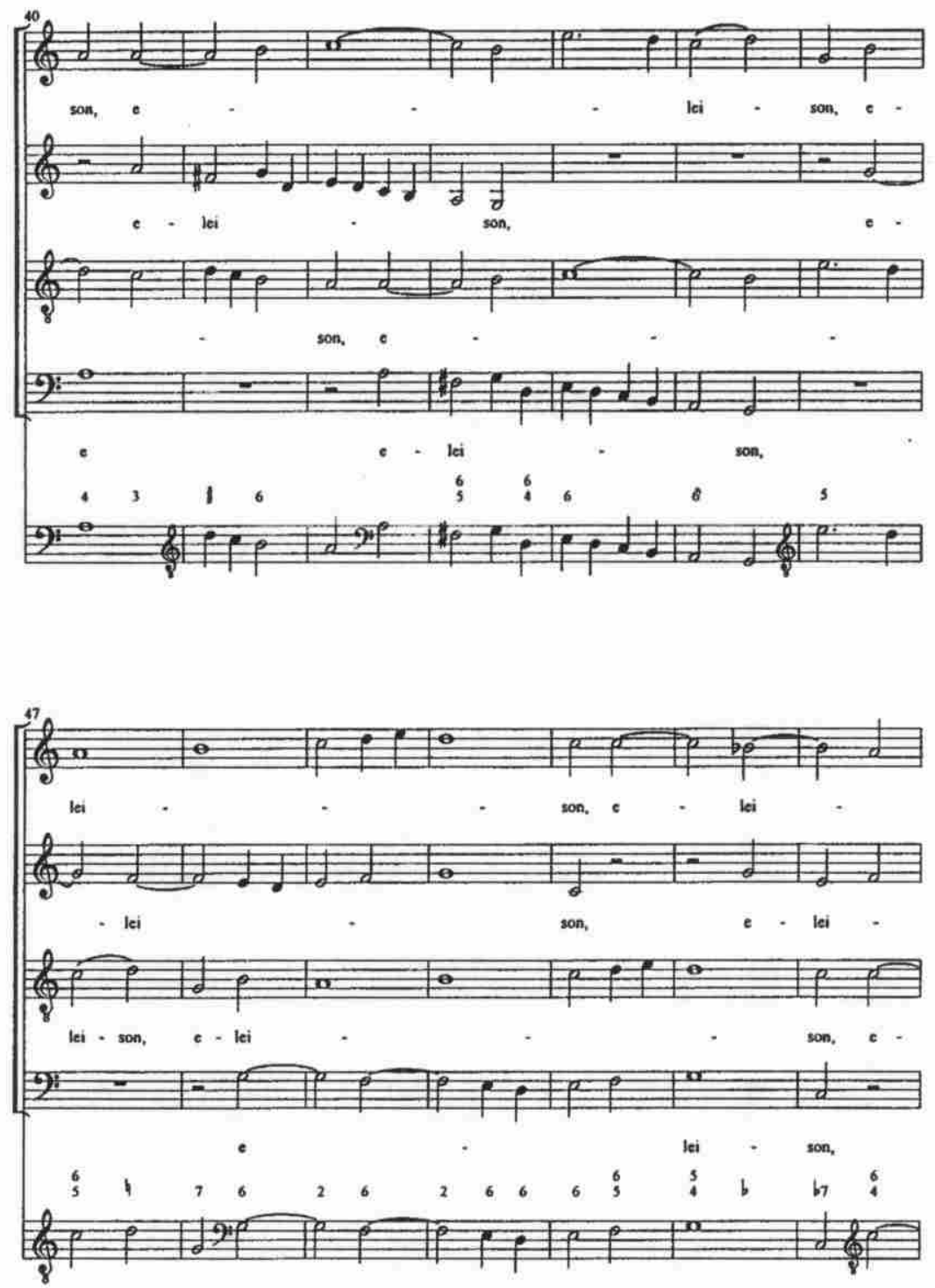

Example 5 (cont'd). Georg Reutter, Jr., Missa a capella, Kyrie I, mm. 4053. 

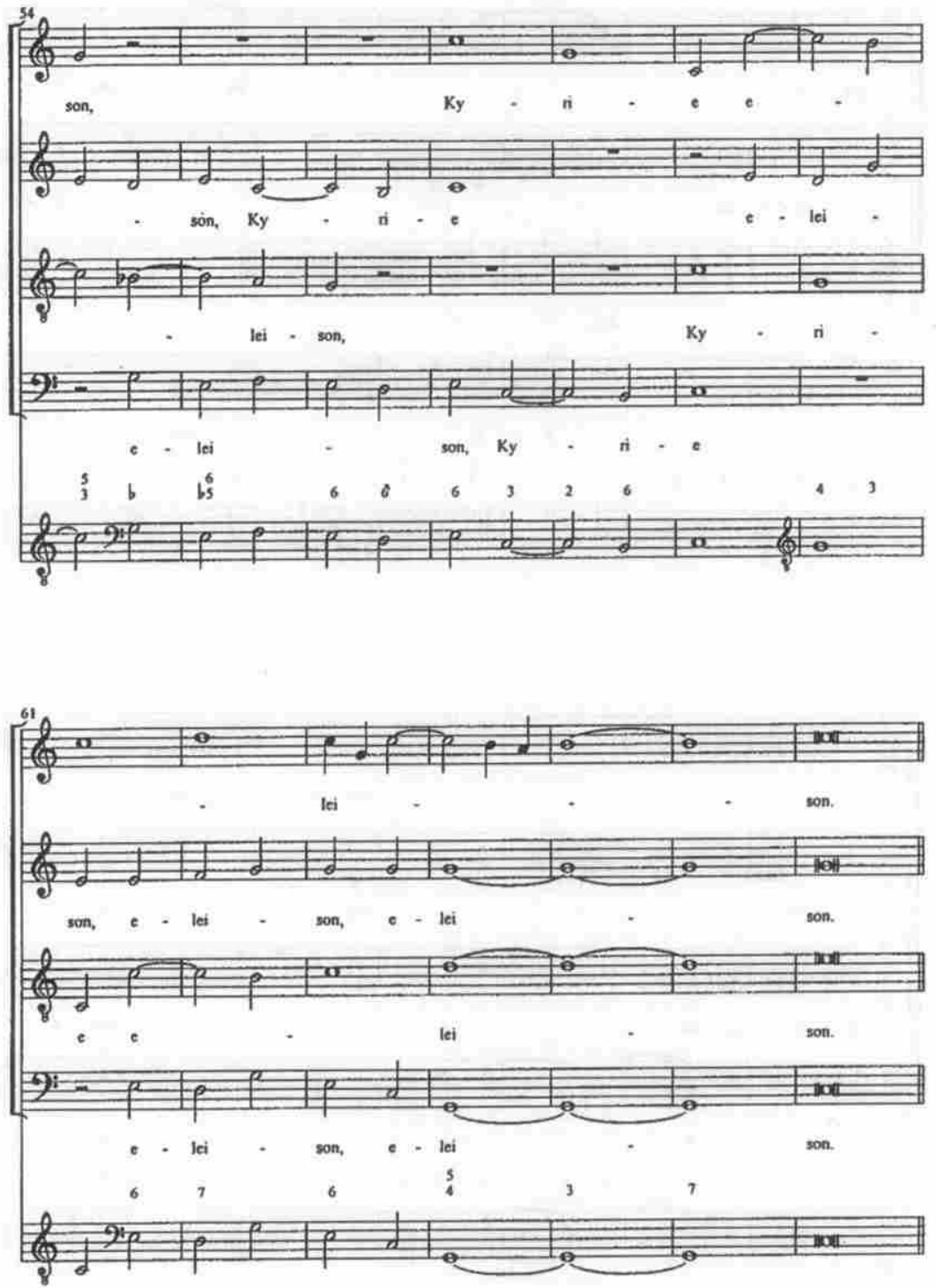

Example 5 (cont'd). Georg Reutter, Jr., Missa a capella, Kyrie I, m. 54 to end. 


\begin{tabular}{|c|c|}
\hline \multicolumn{2}{|l|}{ Kyrie } \\
\hline Kyrie 1 & S-T: $8^{\text {ve }}$ below, A-B: $8^{\text {ve }}$ below \\
\hline Christe & T-S: $8^{\text {ve }}$ above, A-B: $8^{\text {ve }}$ below \\
\hline Kyrie 2 & A-S: $2^{\text {nd }}$ above, B-T: $5^{\text {th }}$ above \\
\hline \multicolumn{2}{|l|}{ Credo } \\
\hline Patrem omnipotentem & A-B: $8^{\text {ve }}$ below, T-S $8^{\text {ve }}$ above \\
\hline Visibilium omnium & A-T-B-S: $5^{\text {th }}$ below, $8^{\text {ve }}$ below, $4^{\text {th }}$ above \\
\hline Et in unum Dominum & A-T: $5^{\text {th }}$ below \\
\hline Filium Dei unigenitum & S-B: $6^{\text {th }}$ below \\
\hline Et ex Patre natum & A-S: $4^{\text {th }}$ above \\
\hline Ante omnia saecula & T-B: $5^{\text {th }}$ below \\
\hline Genitum non factum & B-A: $9^{\text {th }}$ above, T-S: $9^{\text {th }}$ above \\
\hline Qui propter nos homines & T-B: $5^{\text {th }}$ below, S-A: $5^{\text {th }}$ below \\
\hline Et incarnatus est & homophony \\
\hline Et homo factus est & imitation \\
\hline Crucifixus & A-B: $8^{\text {ve }}$ below \\
\hline Etiam pro nobis & $\mathrm{S}-\mathrm{T}: 7^{\text {th }}$ below \\
\hline Et resurrexit & S-A: $5^{\text {th }}$ below \\
\hline Et ascendit & B-T: $5^{\text {th }}$ above \\
\hline Et iterum venturus est & S-A: $5^{\text {th }}$ below \\
\hline Judicare vivos et mortuos & B-T: $4^{\text {th }}$ above \\
\hline Huius regni non erit finis & T-S-B-A: $8^{\text {ve }}$ above, $5^{\text {th }}$ below, $4^{\text {th }}$ above \\
\hline Et in Spiritum Sanctum & A-B: $8^{\text {ve }}$ below, T-S: $8^{\text {ve }}$ above \\
\hline Qui cum Patre & B-T: $4^{\text {th }}$ above \\
\hline Simul adoratur & A-S: unison \\
\hline Et unam sanctam catholicam & S-A: $5^{\text {th }}$ below \\
\hline Confiteor & T-B: $5^{\text {th }}$ below \\
\hline Et exspecto resurrectionem & imitation \\
\hline Et vitam venturi & fugue \\
\hline Sanctus & S-A-T-B: $4^{\text {th }}$ below, $7^{\text {th }}$ below, $10^{\text {th }}$ below \\
\hline \multicolumn{2}{|l|}{ Benedictus } \\
\hline Benedictus & T-B: mirror canon \\
\hline Osanna & fugue \\
\hline \multicolumn{2}{|l|}{ Agnus Dei } \\
\hline Agnus Dei 1 & A-S: $5^{\text {th }}$ above \\
\hline Miserere nobis & T-B: $4^{\text {th }}$ below \\
\hline Agnus Dei 2 & T-A-B-S: $4^{\text {th }}$ above, $4^{\text {th }}$ below, $8^{\text {ve }}$ above \\
\hline Dona nobis pacem & T-S: $8^{\text {ve }}$ above, B-A: $8^{\text {ve }}$ above \\
\hline Dona nobis pacem (repetition) & T-S: $8^{\text {ve }}$ above, A-B: $8^{\text {ve }}$ below \\
\hline
\end{tabular}

Figure 2. Canons in Reutter, Missa a capella. Intervals greater than a tenth have been reduced to their smallest octave equivalents. In four-part canons the intervals of imitation from the leading voice are indicated. 
ciple of the tonal idiom at the very outset, unambiguously and unequivocally. By contrast, the subject of Fux's Kyrie had mediated against such harmonic clarity. The modality of the Messa di San Carlo therefore results more from the nature of the thematic material than from the genre of the work. The music carefully preserves an impression of linear flow, a quality for which Fux expresses a marked preference throughout the Gradus. ${ }^{39}$

The tonic-dominant opposition clarified at the opening of Reutter's Kyrie extends to the movement as whole, in which the keys of $\mathrm{C}$ major and $\mathrm{G}$ major outline a roughly ternary form. A motion to the dominant occurs in measure 10 in the fashion most typical of tonal music, the raising of the fourth scale degree. This motion does not establish $\mathrm{G}$ major strongly, however. $\mathrm{C}$ major begins to return in measure 17 , but gives way again to $\mathrm{G}$ major at measure 28 . The departure from the tonic now has more permanence, as there follows a move to the submediant key of A minor at measure 34. A return to the dominant at measure 41 initiates a descent through the circle of fifths that reaches the subdominant key area beginning at measure 52. This traversal of the flat side of the tonal spectrum lasts briefly, for there soon follows a final, decisive return of $\mathrm{C}$ major, accompanied by a restatement of the principal subject. Reutter thus articulates an emphatic recapitulation through a coordination of harmonic and thematic means, a procedure that would, of course, assume great importance during the succeeding decades.

However, other than at this recapitulation, the tonal areas of the movement do not stand sharply apart but succeed one another in a rather fluid manner, thus manifesting some of the essential linear

39. Fux's partiality toward diatonicism stems from his belief in the preeminence of the human voice. He insists on this preeminence throughout the Gradus, repeatedly offering reminders that melodic lines must be designed so that they can be sung comfortably and naturally. His use of the traditional C-clefs and his recommendation that the limits of the staff not be exceeded are symptomatic of this concern for singability. Fux's attention to this issue is such that Josephus must at one point justify his use of flats to Aloysius in the following manner: "these flats would not interfere with the diatonic system since they were not used functionally, but nonessentially." (Gradus ad Parnassum, 69. Translation from Mann, The Study of Counterpoint, 54).

40. See measures 17-21, in which triads on adjacent pitches alternate in a manner similar to the opening of the Messa di San Carlo. 
quality of the stile antico ${ }^{40}$ Nevertheless, in its initial opposition of tonic and dominant keys and its return to the tonic prepared by a brief visit to the subdominant, this Kyrie clearly embodies a tonal scheme that assumed paradigmatic status in the later eighteenth century, especially as codified in sonata form.

The presence of a basso continuo part contributes to the progressive character of Reutter's Mass by highlighting the vertical aspect of its music. ${ }^{41}$ The figures in this part often indicate pitches not present in the voices, thereby filling out otherwise incomplete harmonies. This technique forms an especially important resource because of the constraints imposed on melodic flexibility by the canonic writing. Examples of the clarification of harmonies by the continuo in the opening Kyrie include the seventh in the second half of measure 8 and the sixth in the second half of measure 10. In both instances a dominant-tonic progression is strengthened by the additional note: In the first, the note generates a dominant-seventh sonority; in the second, it provides the missing tonic root. The most striking case of this procedure occurs at the end of the movement. During the final cadence, as the singers hold a dominant harmony for three measures, the continuo introduces a seventh in the last measure before the concluding tonic chord. This note particularly stands out because it makes its appearance as the other voices remain stationary. The heightening of the closing cadential progression in this manner illustrates the important role played by the continuo in defining the harmonic component of the music. The integration of a prominent vertical element with the linear manner of the stile antico in this Mass demonstrates Reutter's more modern orientation as compared to Fux.

41. During the eighteenth century, the scoring of so-called a cappella music often featured a continuo complement (usually organ and violone) and doubling instruments. This shows that the expression a cappella did not mean purely vocal sonority at this time, but that it denoted the absence of obbligato instrumental parts. In the Gradus ad Parnassum, Fux differentiates two types of stylus a cappella (pp. 243-273). The first, without instruments, demands strict diatonicism because unaccompanied voices experience difficulty in singing chromatic notes. The second, with instruments, permits greater melodic and harmonic freedom. Although the possibility of including a continuo element certainly aided the gradual absorption of tonality by the Palestrina style, by the second half of the eighteenth century even stile antico works for voices alone had largely abandoned the church modes. See my Tradition and Ideal of the Stile Antico, 131-142. 
The last of the three works under consideration, Albrechtsberger's Missa in $C$, reveals a full-fledged tonality. Like Reutter's Missa a capella, it includes a basso continuo part. None of the surviving sources of the Mass provides a date of composition, although we can assume a terminus post quem of the mid-1750s, the period to which Albrechtsberger's earliest securely dated music belongs. ${ }^{42}$ The principal subject of the opening Kyrie lays out a tonal space in a fashion that recalls Reutter, but does so with greater sophistication (Example 6). Instead of simply marking the tonic and dominant pitches, Albrechtsberger shapes the contour of his subject so that it clearly hints at a basic I-IV-V-I progression. This opening thus exemplifies the notion, fundamental to tonality, that an unharmonized melody suggests a harmonization.

Confirmation of the implied progression (with some elaborations) arrives in measures 7 to 10 , at the entrance of the bass voice in the point of imitation. This bass serves a dual function, both acting as a strand of the contrapuntal texture and providing a harmonic fundament. The integration of horizontal and vertical aspects in the subject becomes manifest here. As the movement proceeds, Albrechtsberger harmonizes the subject differently, as at measures

42. See Schroeder's catalogue, which organizes the composer's sacred output by genre, key, and chronology. The title Missa in $C$ is a generic one assigned by Schroeder, in the absence of any surviving early manuscripts that provide a name for the work. I have had the opportunity to examine a source for the Mass in the archives of Heiligenkreuz Abbey in Lower Austria (A-HE I a 4). This source consists of parts prepared by no less than four hands, two roughly contemporary with Albrechtsberger's lifetime and two from a significantly later period. The title on a box enclosing the parts reads "Messe No. 4 in C dur für 4 Singstimmen, Violon u. Orgel von Georg Albrechtsberger." However, this box must date from well after the eighteenth century, as is evident from the use of German rather than of Latin or Italian. The paper cover (Umschlag) typically found in sources of eighteenth-century and early nineteenth-century Austria that would have indicated a title has disappeared. I have not been able to determine an approximate date of composition on the basis of the handwriting and paper-types of the earlier parts. However, a comprehensive study of musical life at Heiligenkreuz that includes detailed investigation of the preparation, acquisition, and transmission of manuscript sources could well produce substantive discoveries concerning individual works that made up the active repertoire at this important monastic institution. The potential fruits of this kind of research are well demonstrated by Robert N. Freeman's The Practice of Music at Melk Abbey Based Upon the Documents, 1681-1826 (Vienna: Österreichische Akademie der Wissenschaften, 1989). 

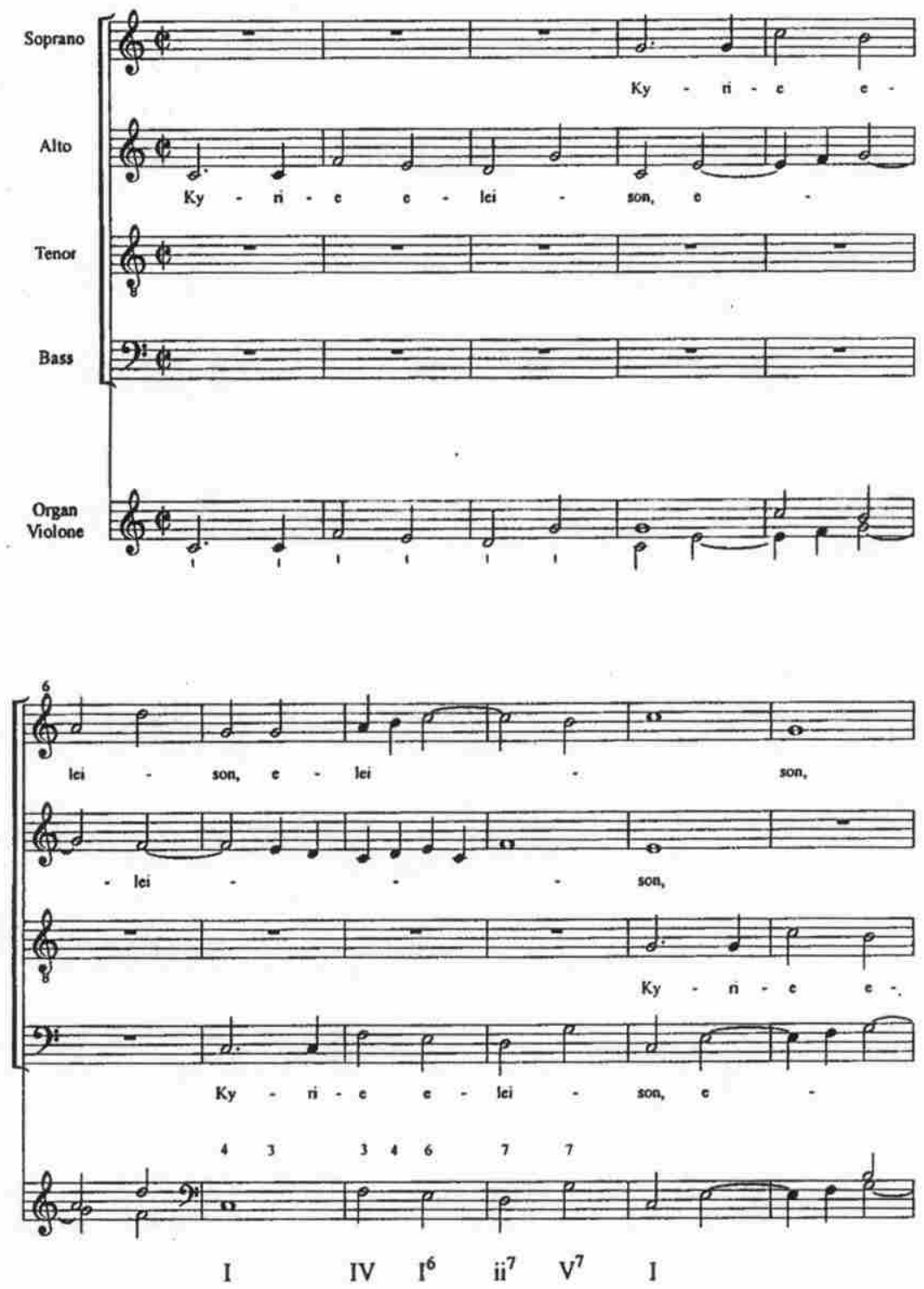

Example 6. Johann Georg Albrechtsberger, Missa in C, Kyrie I, mm. 111. 

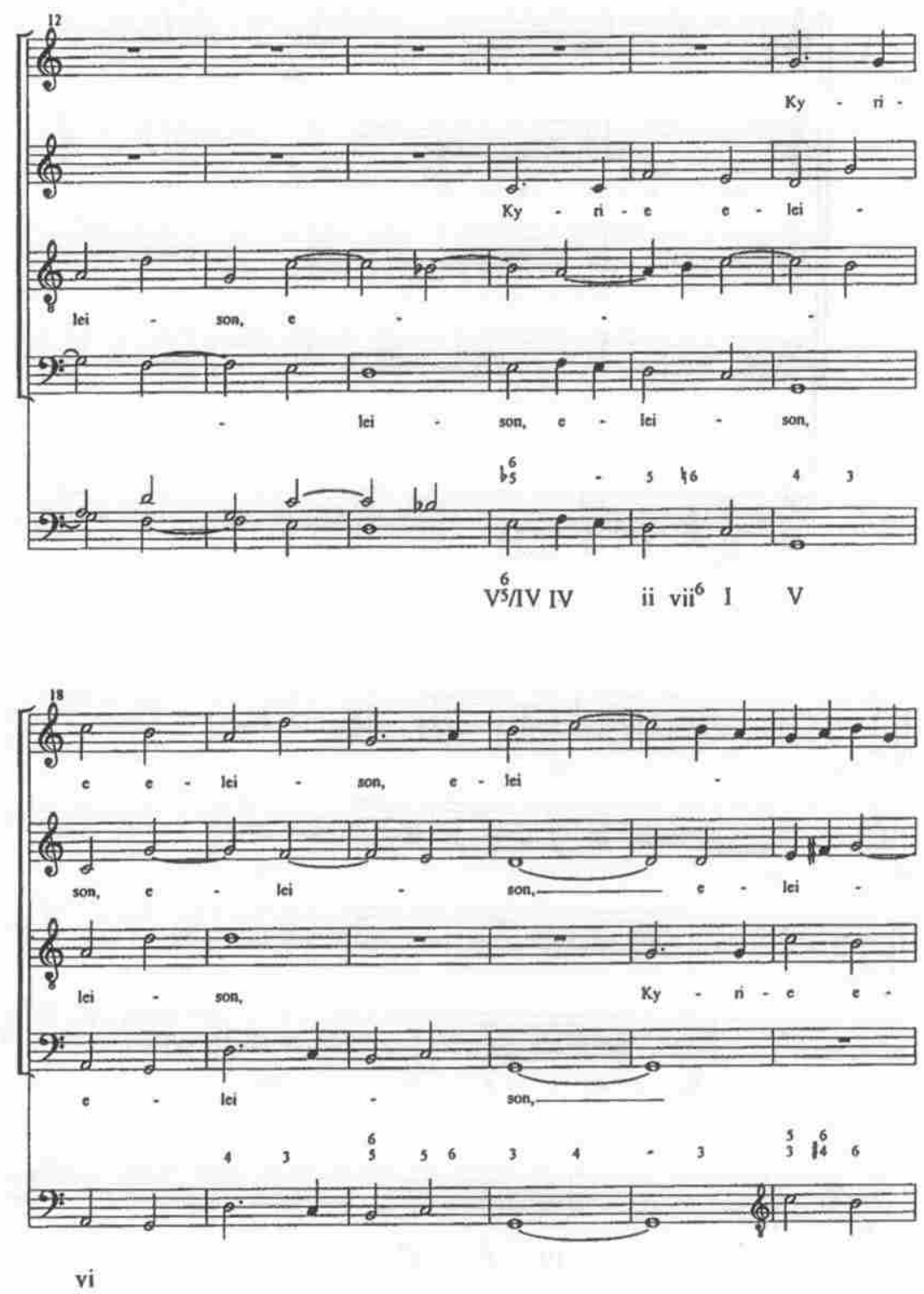

Example 6 (cont'd). Johann Georg Albrechtsberger, Missa in C, Kyrie I, mm. 12-23. 
15 to 18 , where the progression is a colorful $V^{6}{ }_{5}, I V-I V$-ii-vii 6 -I-V-vi (forming part of a stretto passage). The composer allows his imagination free play in exploring the possibilities offered by his subject. A developed tonal language furnishes the context in which this imagination can flourish.

Albrechtsberger, like Reutter, employs the device of a highly articulated reestablishment of the home key. However, he achieves a more compelling return by means of a slightly expanded harmonic vocabulary and a strategic coordination of the components of this vocabulary. The passage from the Credo cited in Example 7 visits the keys of the tonic, dominant, submediant, and mediant. However, in contrast to the fluidity of Reutter's Kyrie, here a series of cadences clarifies the boundaries of the key areas. A total of nine cadences occurs in this passage, in G major (m. 123), C major (mm. 126, 145, 149, 157), A minor (mm. 132, 154), and E minor (mm. 136, 141). These cadences mark the ends of individual segments of text, with each segment set to an individual thematic idea presented in imitation by a pair of voices (either soprano-alto or tenor-bass).

The rapid modulation of these measures produces an effect of tonal instability, with the delineation of harmonic areas contributing to the effect by heightening the juxtaposition of contrasting elements. Albrechtsberger thereby sets the stage for a striking reaffirmation of the home key. Beginning at measure 157, he grounds the music in C major with a steady and insistent alternation of tonic and dominant harmonies. Complementing the impact of the reappearance of firm tonal ground is a shift from imitative two-part texture to four-voice homophony that illustrates, in characteristic fashion, the words "simul adoratur et conglorificatur." The expressive strength of this important moment of the Mass demonstrates the extent to which Albrechtsberger had assimilated the aesthetic of a dramatized return associated with tonality into strict composition. At the same time that he maintained the characteristic polyphonic manner of the stile antico, he drew on the harmonic resources offered by contemporary musical style to enrich the idiom.

Albrechtsberger's theoretical writings provide a confirmation of the transformation of the stile antico that had occurred in his works and those of his contemporaries. The most important of these writings, the Gründliche Anweisung zur Composition (Leipzig, 1790), reformulates Fux's rules of species counterpoint to make them suit a 

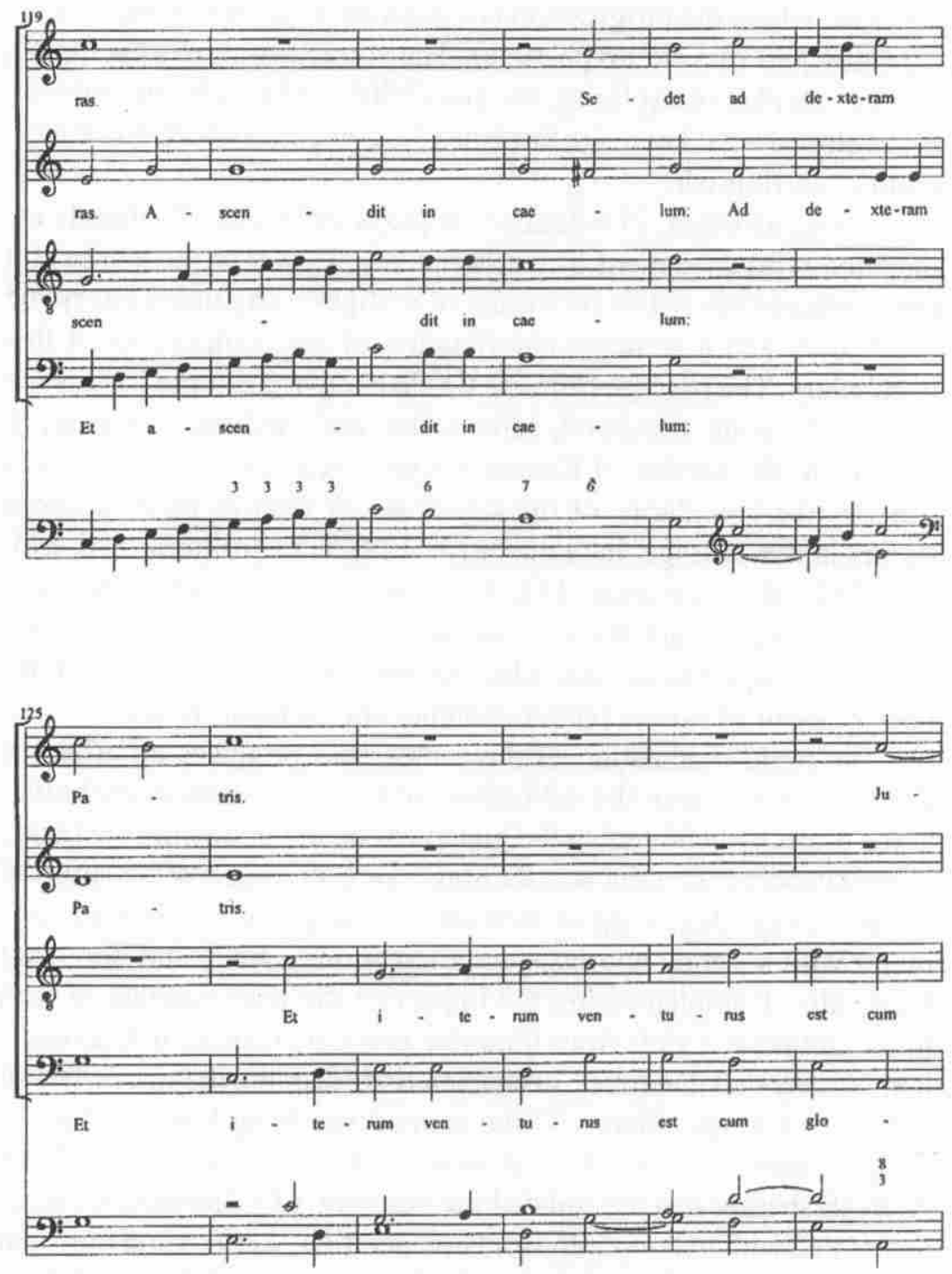

Example 7. Johann Georg Albrechtsberger, Missa in C, Credo, mm. 119130. 

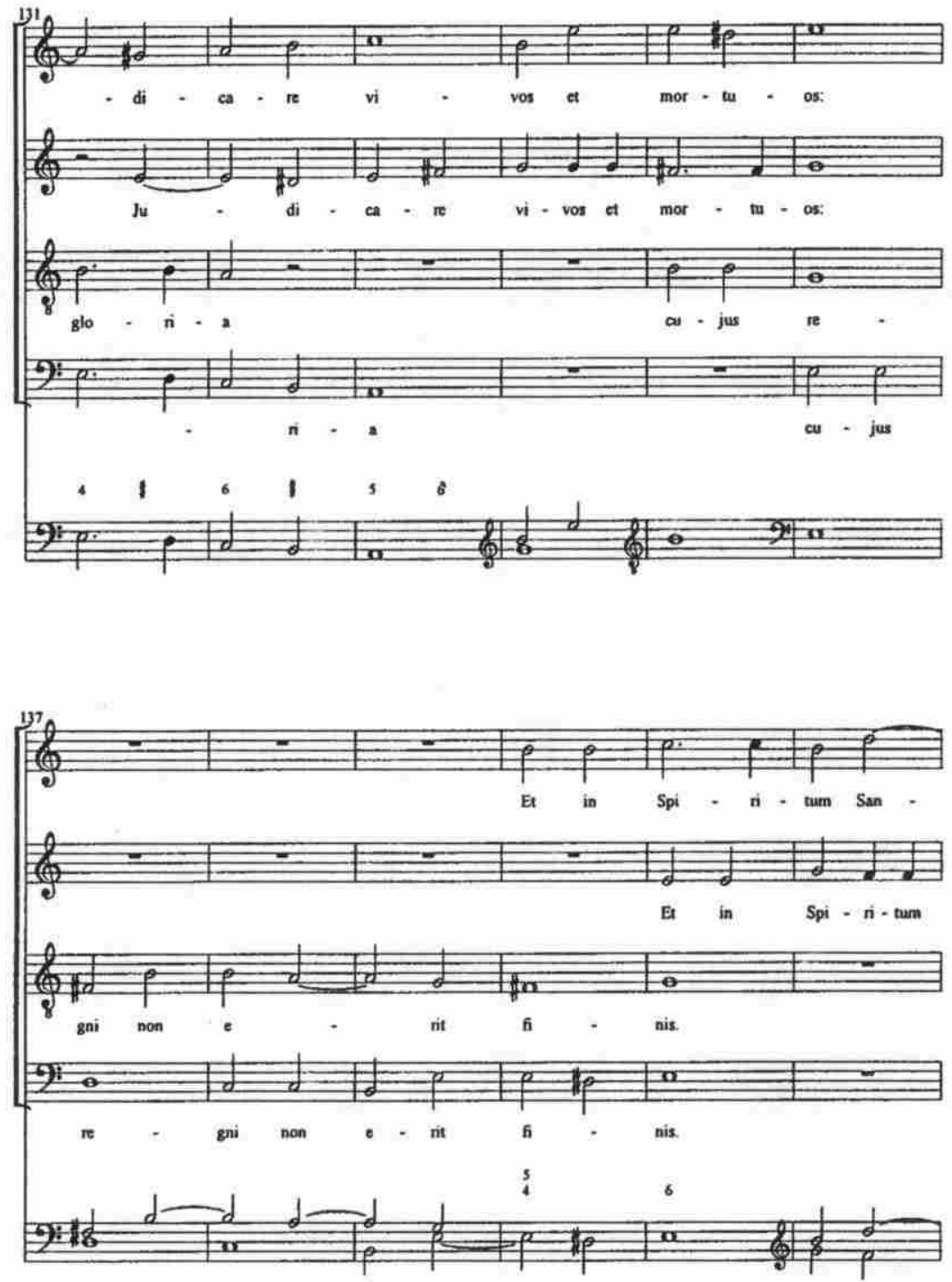

Example 7 (cont'd). Johann Georg Albrechtsberger, Missa in C, Credo, mm. 131-142. 

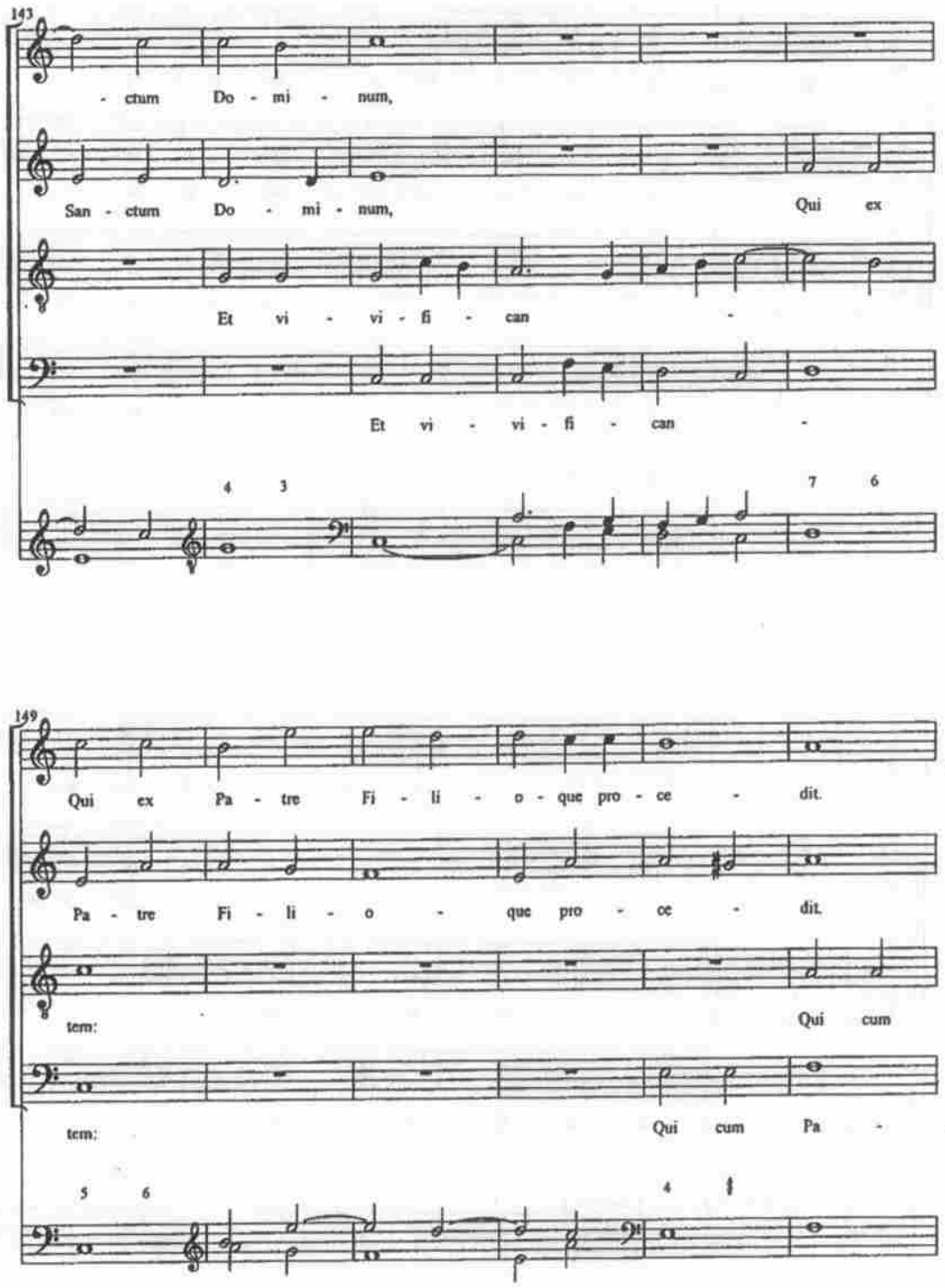

Example 7 (cont'd). Johann Georg Albrechtsberger, Missa in C, Credo, mm. 143-154. 

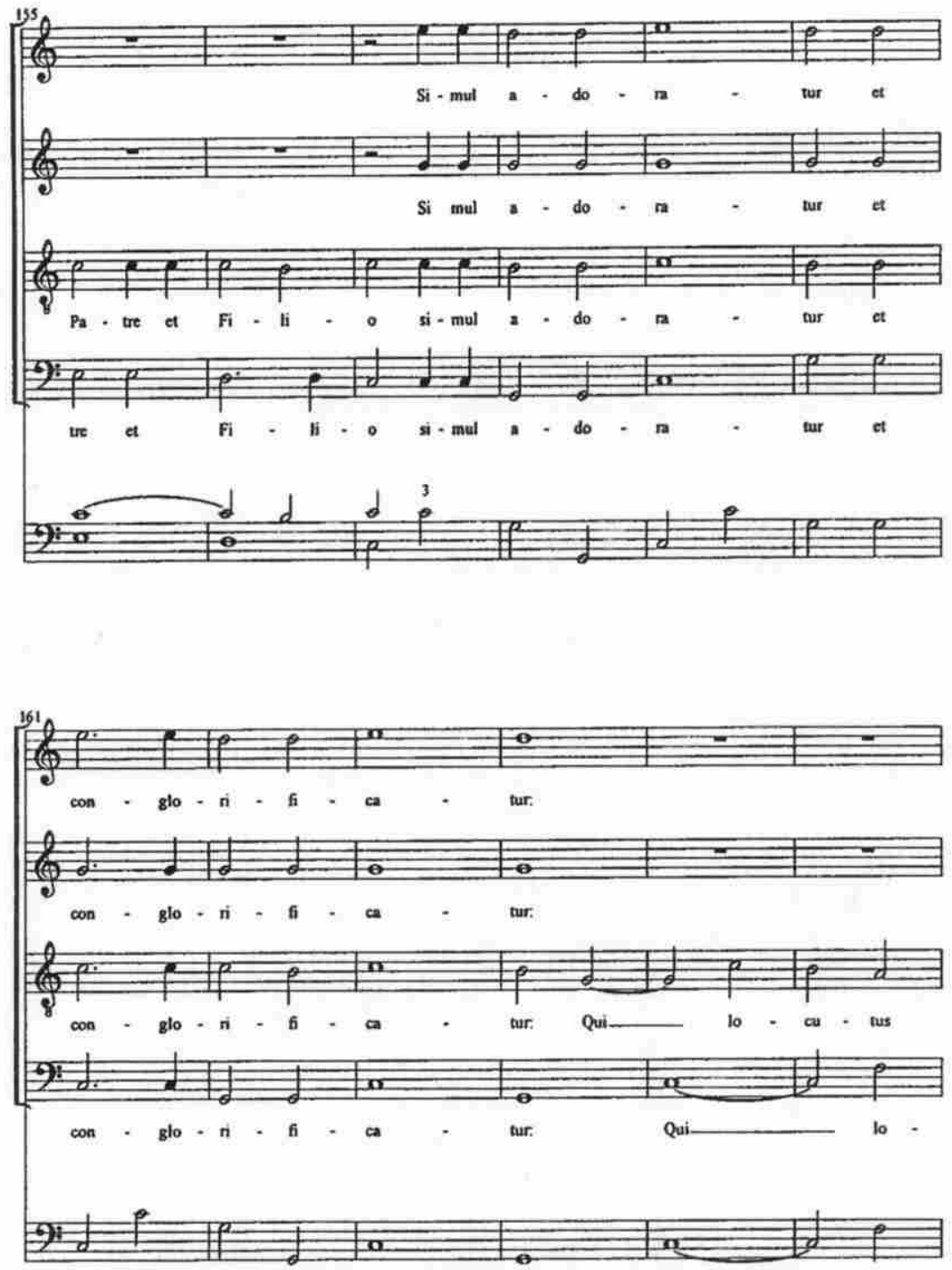

Example 7 (cont'd). Johann Georg Albrechtsberger, Missa in C, Credo, mm. 155-166. 
modern stylistic context. ${ }^{43}$ Its overall format follows that of the Gradus ad Parnassum, so that, for example, Albrechtsberger, like Fux, progresses through the five species first in two voices, then in three, and finally in four. The later writer reveals a strong consciousness of the work of the earlier, yet feels free to modify it according to the needs of his own age. Although Albrechtsberger is usually considered one of the more conservative figures in Viennese musical life of the late eighteenth century, he nevertheless did not promote strict counterpoint in a form that would render it archaic and irrelevant.

The traditional church modes had occupied a central place in the Gradus in the form of the four cantus firmi (one each for the Dorian, Phrygian, Lydian, and Mixolydian modes) used in all of Fux's species counterpoint exercises (see Example 8). By contrast, in an early section of the Anweisung dealing with the basic materials of music which corresponds to a similar section in the Gradus, Albrechtsberger dismisses the modes summarily, calling them an ancient practice and referring any interested readers to earlier writings. ${ }^{44} \mathrm{He}$ then follows with an extended discussion of the 24 major and minor keys, thereby implying their greater importance. Further indications of his more contemporary outlook vis-à-vis Fux include his treatment of dissonance as a chordal rather than an intervallic phenomenon ${ }^{45}$; his tacit assumption of a prior familiarity with the principles of thoroughbass and his consequent use of figured-bass notation to identify harmonies throughout the treatise; and, most tellingly, his advice to draw upon knowledge of thoroughbass when proceeding from two-voice to three-voice counterpoint, as two notes always imply a third. ${ }^{46}$

Although the Anweisung represents the most comprehensive updating of the Palestrina style during the later eighteenth century, other theoretical documents of the period demonstrate a comparably mod-

43. A freely expanded version by Ignaz von Seyfried of the treatise appeared as part of the collection J. G. Albrechtsbergers Sämtliche Schriften über Generalbass, Harmonie-Lehre, und Tonsetzkunst, zum Selbstunterrichte (Vienna: Anton Strauss, 1837). This collection was translated by Sabilla Novello as J. G. Albrechtsberger's Collected Writings on Thorough-Bass, Harmony, and Composition, for Self-Instruction (London: Novello, Ewer, \& Co., 1855). Portions of Albrechtsberger's discussion of fugue are translated by Mann in The Study of Fugue, 213-262.

44. Gründliche Anweisung zur Composition, 7-8.

45. Ibid., 17.

46. Ibid., 75 . 

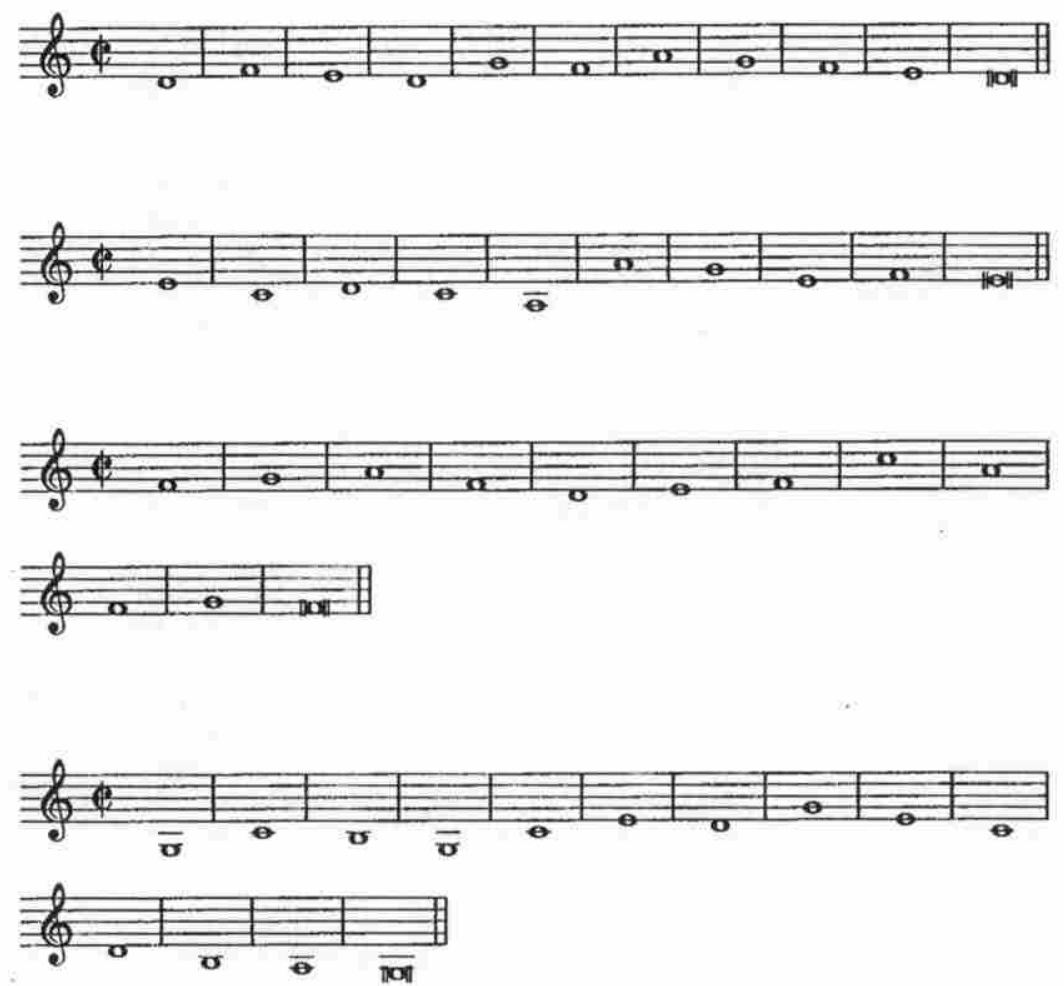

Example 8. Johann Joseph Fux, cantus firmi from Gradus ad Parnassum.

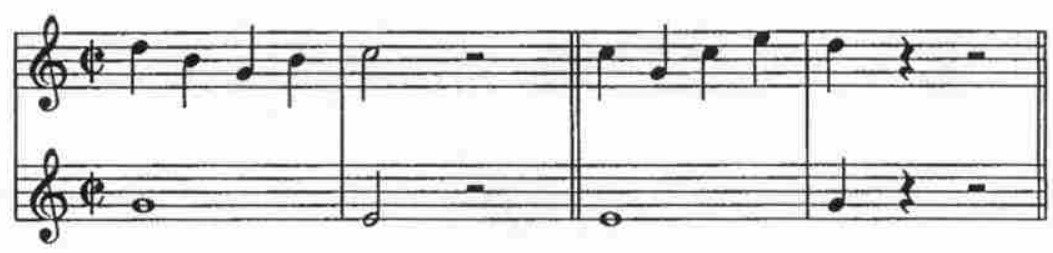

Example 9. Joseph Haydn, from the Elementarbuch, p. 15. 
ernized perspective. The abstract of Fux's rules of species counterpoint prepared by Joseph Haydn for his students and known as the Elementarbuch offers an option for setting four quarter notes against a whole note that consists of a broken triad, a pattern Fux could not have advocated (Example 9). ${ }^{47}$ This arpeggiation diverges from Fux's strictly linear conception of the stile antico, and manifests a harmonic thinking that regards a succession of notes as the horizontal separating out of a verticality. A similar arpeggiation appears in the so-called Attwood studies, the record of Thomas Attwood's lessons with Mozart that took place during the mid-1780s. ${ }^{48}$ In the exercise presented in Example 10, Mozart corrects the antepenultimate measure to produce a descending triad, evidently because this solution offered better balance and variety. ${ }^{49}$ In the studies of a different Mozart student, Barbara Ployer, one finds an illustration of the notion that two notes connote a third. ${ }^{50}$ When Ployer sets the pitch $b$ ' against $d$ ' in a second species exercise (Example 11, m. 8), Mozart marks the interval of the sixth as incorrect because it suggests to him a diminished triad, which should not occur on a downbeat. ${ }^{51}$ He thus evaluates the interval not

47. The manuscript of the abstract - copied and dated 1789 by one "F. C. Magnus," who must have studied with Haydn - is now housed at the National Széchenyi Library in Budapest (shelf mark Ha I 10). For a translation with commentary, see Alfred Mann, "Haydn's Elementarbuch: A Document of Classic Counterpoint Instruction,” The Music Forum 3 (1973), 197-237. Mann notes the arpeggiated patterns on p. 232 of his translation.

48. Transcription of the studies in Daniel Heartz, Erich Hertzmann, Alfred Mann, and Cecil B. Oldman, eds., Thomas Attwoods Theorie- und Kompositionsstudien bei Mozart, in W. A. Mozart: Neue Ausgabe sämtlicher Werke X/30/1 (Kassel: Bärenreiter, 1965).

49. Thomas Attwoods Theorie- und Kompositionsstudien bei Mozart, 61. Mann cites the exercise in "Haydn's Elementarbuch," 232. In addition to relieving a certain monotony of melodic movement, Mozart's revision eliminates the stepwise motion that continues in the same direction as the immediately preceding leap of a sixth. For most of the emendations in the studies there exists no written clarification, and one therefore has to attempt a speculative reconstruction of Mozart's thinking.

50. Transcription of the studies in Hellmut Federhofer and Alfred Mann, eds., Barbara Ployers Theorie- und Kompositionsstudien bei Mozart, in W. A. Mozart: Neue Ausgabe sämtlicher Werke X/30/2 (Kassel:, 1989).

51. Barbara Ployers Theorie- und Kompositionsstudien bei Mozart, 42-43. Lester discusses this exercise in Compositional Theory in the Eighteenth Century, 186-187. Mozart does not provide an alternative counterpoint; on the other hand, he explains the problem of the diminished triad in a rare written annotation. 

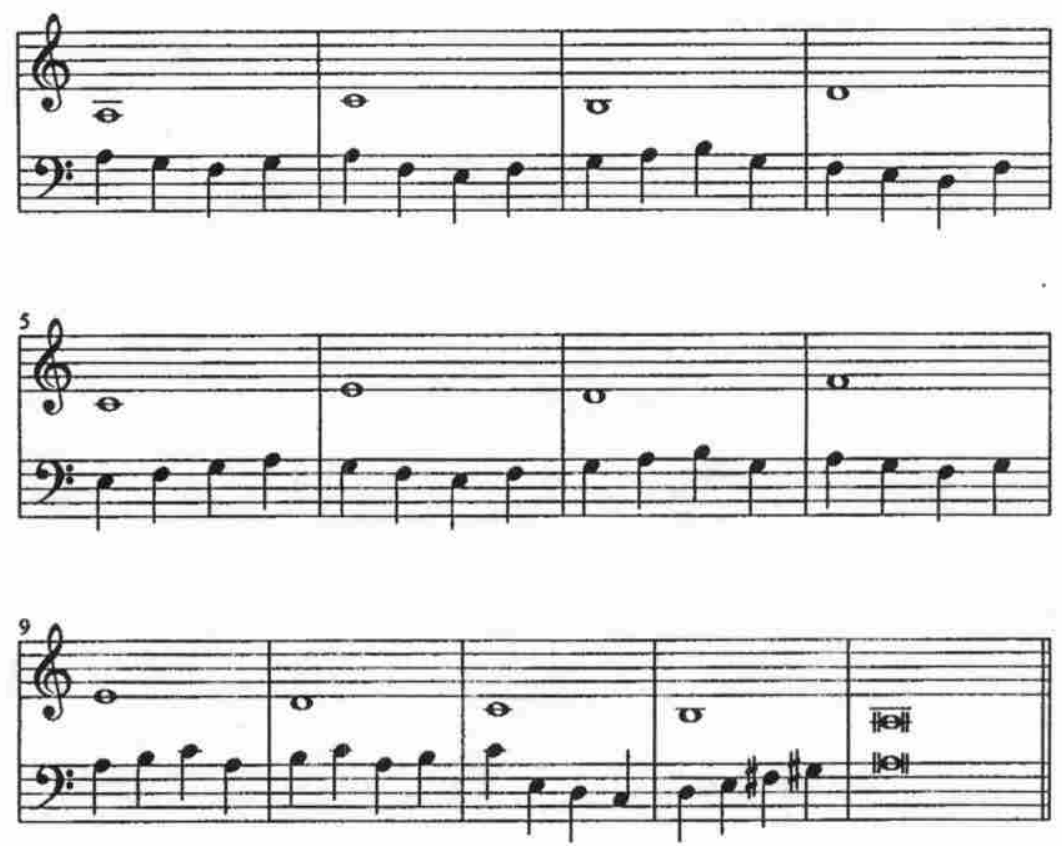

Mozart's correction:

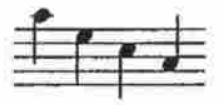

Example 10. Wolfgang Amadeus Mozart, from the Attwood Studies, p. II/29.

according to the degree of dissonance generated by its two elements, but on the basis of a larger harmonic context that includes the implicit third pitch $f^{\prime}$.

The foregoing discussion of musical examples and theoretical writings will help to illuminate the manner in which the stile antico absorbed contemporary developments in musical language during the second half of the eighteenth century. The synthesis of functional tonality and linear-diatonic counterpoint demonstrates the remarkable adaptability of the principles of vocal polyphony. It thus offers compelling support of Fux's view of the unchanging validity of these principles, perhaps in a way that the imperial Kapellmeister could not have foreseen. The assimilation of the idiom with a new system of harmonic organization reveals that the practice of strict composition did not require modality as a precondition for its successful cul- 

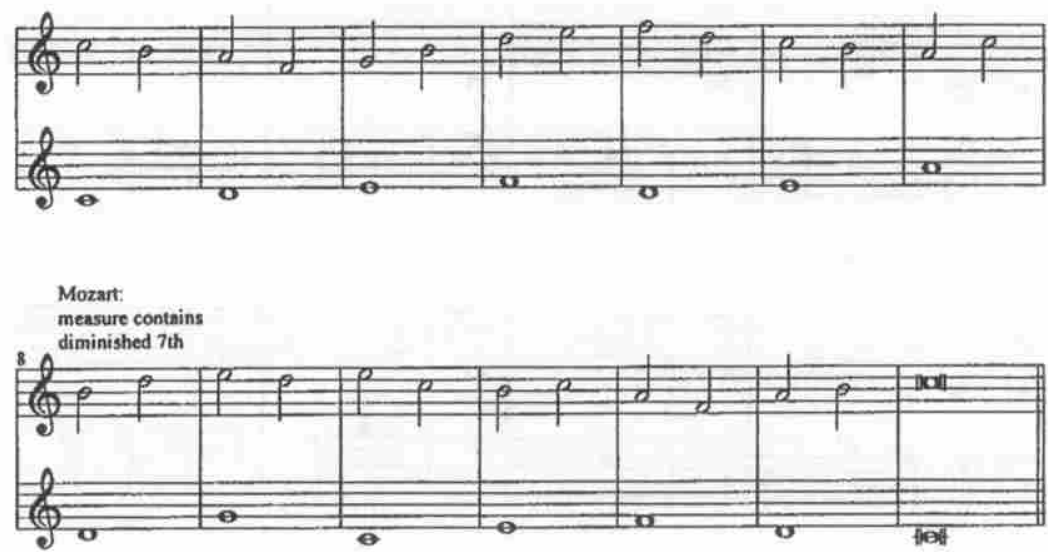

Example 11. Wolfgang Amadeus Mozart, from the Ployer studies, fol. 11'.

tivation. Put another way, the stile antico transcended the boundaries of a time period in which modality prevailed, and thereby exemplified the Fuxian conception of timelessness.

Herein lies a key to understanding the degree of attention given to the Palestrina style in eighteenth-century Vienna. An ideal of permanence belonged among the central attitudes of this deeply pious milieu. The devout Roman Catholic climate of the Habsburg capital undoubtedly played a role in the enormous success of the Gradus, for the work not only codified the precepts of the stile antico but also transmitted a set of cultural and musical values that resonated deeply with the times. During the eighteenth century, the craft and discipline exemplified by the practice of strict counterpoint possessed an important religious dimension. Because Catholic belief placed special emphasis on the qualities of universality and objectivity, a musical art predicated on a close adherence to eternal laws naturally held sway. Even as a rising interest in the mysteries of inspiration and genius took hold toward the end of the century, the distinctive attitudes embodied in the stile antico remained influential. The phenomenon of the stile antico during the eighteenth century thus provides essential insights into music's meanings and significances for composers and audiences of this period. 
Copyright $@ 2003$ EBSCO Publishing 